\title{
Göç, Kentsel Dönüşüm ve Devingenlik İlişkisinin Yapılmış Araştırmalar Üzerinden Okunması
}

\author{
Ceren Ağin ${ }^{1 *}$, Hayat Zengin Çelik ${ }^{2}$, Senem Tezcan ${ }^{3}$ \\ ${ }^{1 *}$ Dokuz Eylül Üniversitesi, Fen Bilimleri Enstitüsü, Şehir ve Bölge Planlama Anabilim Dalı Öğrencisi, İzmir/Türkiye, \\ Ar. Gör., Muş Alparslan Üniversitesi Mühendislik-Mimarlık Fakültesi Şehir ve Bölge Planlama Bölümü, Muş/Türkiye (ORCID: 0000-0002-2032-4921), \\ c.agin@alparslan.edu.tr \\ 2 Prof.Dr., Dokuz Eylül Üniversitesi, Mimarlık Fakültesi, Şehir ve Bölge Planlama Bölümü, İzmir/Türkiye (ORCID: 0000-0002-4460-2498), hayat.zengin@deu.edu.tr \\ ${ }^{3}$ Dr., Dokuz Eylül Üniversitesi, Fen Bilimleri Enstitüsü, Şehir ve Bölge Planlama Anabilim Dalı Öğrencisi, İzmir/Türkiye (ORCID: 0000-0003-0532-8825), \\ senemtzcn@gmail.com
}

(International Conference on Design, Research and Development (RDCONF) 2021 - 15-18 December 2021)

(DOI: $10.31590 /$ ejosat.1039342)

ATIF/REFERENCE: Ağın, C., Zengin Çelik, H. \& Tezcan, S. (2021). Göç, Kentsel Dönüşüm ve Devingenlik İlişkisinin Yapılmış Araştırmalar Üzerinden Okunması. Avrupa Bilim ve Teknoloji Dergisi, (32), 776-790.

$\ddot{O} \mathbf{z}$

Türkiye kentleşmesini, göç tarihi ile birlikte ele almak mümkündür. Bir başka ifade ile göç ve beraberinde gelişen nüfus hareketleri Türkiye kentleşmesinin önemli bileşenleridir. Cumhuriyetin ilanından itibaren Anadolu coğrafyasında başlayan nüfus hareketleri, farklı etkiler altında Türkiye kentleşmesinin temel dinamiği olmuştur. Dolayısıyla kent ve kentleşmeye dair her inceleme kaçınılmaz olarak göç ve beraberinde gelişen toplumsal ve mekansal etkileri de içerisine almak durumundadır. Bu noktada mekansal süreçler açısından gecekondu olgusu, toplumsal süreçler açısından ise, sınıflı bir toplumsal yapı temel inceleme konuları olarak önümüze gelmektedir. Her ikisi de içerdiği sosyo-ekonomik aç1lımlar temelinde, kentsel yaşamın parçalanmış doğasını ve farklı katmanlardan oluşan kentsel sistem içerisindeki yer değiştirme hareketlerini yani devingenlik şartlarını anlamayı önemli kılmaktadır. Bu noktada kaçınılmaz olarak bu şartlar üzerinde belirleyici olan mekansal müdahaleler önemli hale gelmektedir. Bu çalışma böyle bir anlama sürecinde göçü ve günümüzde çok katmanlı kentsel yapıları yeniden yapılandırmakta olan kentsel dönüşüm uygulamalarını odağa alarak, bu uygulamaların ortaya çıktığı aşamadan itibaren yapılmış araştrımaları makaleler üzerinden ele amaktadır. Ocak 2000-Ekim 2021 tarihleri arasında yapılmış elektronik yayınlar üzerinden devingenlik olgusunun nasıl ele alındığını inceleyen çalışma, dönemsel olarak değişen kentsel müdahaleler ile bu müdahalelere maruz kalan toplumsal kesimlerin değişen koşulları ve bu bağlamda açığa çıkan yeni yer değiştirme hareketleri arasındaki ilişkiyi sorgulamaktadır.

Anahtar Kelimeler: Göç, Devingenlik, Kentsel Dönüşüm, Kavram İncelemesi.

\section{Reading the Relationship between Migration, Urban Renewal and Mobility through Researches}

\begin{abstract}
It is possible to consider the urbanization of Turkey together with the history of migration. In other words, migration and population movements that develop along with it are important components of urbanization in Turkey. Population movements that started in the Anatolian geography since the proclamation of the Republic have been the basic dynamics of urbanization in Turkey under different influences. Therefore, every study of the city and urbanization must inevitably include migration and the social and spatial effects that develop along with it. At this point, the phenomenon of slum in terms of spatial processes, and a classed social structure in terms of
\end{abstract}

* Sorumlu Yazar: c.agin@alparslan.edu.tr

Özel Not: Bu çalışma Prof. Dr. Hayat ZENGİN ÇELİK'in danışmanlığında Ar. Gör. Ceren AĞIN tarafından Dokuz Eylül Üniversitesi Fen Bilimleri Enstitüsü'nde üretilen doktora tezinin bir bölümünden üretilmiştir. 
social processes come before us as the main study subjects. Both, on the basis of the socio-economic expansions they contain, make it important to understand the fragmented nature of urban life and the displacement movements within the urban system consisting of different layers. In other words, it makes it important to understand the conditions of mobility. At this point, spatial interventions that are inevitably determinant on these conditions become important. This study focuses on migration and urban renewal practices that are restructuring multi-layered urban structures in such an understanding process, and discusses the researches made since the emergence of these practices through articles. The study, which examines how the phenomenon of mobility is handled through electronic publications made between January 2000 and October 2021, questions the relationship between periodically changing urban interventions, the changing conditions of the social segments exposed to these interventions, and the new displacement movements that emerge in this context.

Keywords: Migration, Mobility, Urban Renewal, Concept Review.

\section{Giriş}

Kentleşme Chicago Okulunun yanı sıra Harvey, Castells, Weber gibi çeşitli kuramcıların ortaya koyduğu çerçevede, iki yönlü bir olgudur. Bir yandan nüfusun belli bir büyüklük ve yoğunluğa ulaşmış ve tarım dışı faaliyetin etkin olduğu heterojen bir yapı olarak tarif edilirken, diğer yandan "kent kültürü"ne yani davranış, değer ve tutumların farklılaşan içeriği temelinde ortaya çıkmaktadır. Modern kentin içeriğini betimleyen bu koşullar dünyada uzun bir perspektifte kente dair ele alışları yönlendirmiş olmakla birlikte, Türkiye kentleşmesinde kendine özgü açılımlar kazanmıştır. Bunun sebebi Türkiye kentleşme pratiğinin ilk aşamadan itibaren kır-kent ikileminde ve birbirinin içine geçmiş bir yapı olarak biçimlenmiş olmasıdır. $\mathrm{Bu}$ nedenledir ki, ülkemizde "kentleşme" kavramı giderek "kentlileşme" tanımlamasını da beraberinde getirmiştir. Kentlileşme, en genel tanımıyla kırdan kentlere göç eden toplulukların, ekonomik, sosyal, kültürel açılardan kentin yarattığı ortama uyumlanma süreci olarak tanımlanmaktadır (Keleş, 2015). Söz konusu uyumlanma sürecinin ekonomik, kültürel vb. farklı açılardan gerçekleşmesi kente atfedilen ayrıcalıklı konum çerçevesinde beklenen bir durumdur. Ancak bu beklentinin hayata geçebilmesi bireyler ve toplumlar için yaşam şartlarını geliştirmeye açık bir ortamın varlığg ve dolayısıyla devingenlik kanallarının ne kadar açık olduğu ile ilgilidir. Bu bağlamda ülkesel şartlarda ulaşılmış olan refah düzeyi önemli hale gelmekte olup, ülkemiz koşullarında beklenen hedeflere ulaşılamamış olması nedeni ile, ağırlıkla kır-kent ikileminde gelişen sınıflı bir toplum yapısı hep varlığını korumuştur. $\mathrm{Bu}$ çerçevede dönemsel olarak değişen şartlara bağlı olarak göç eden topluluklar için katmanlaşmış bir toplumsal yapı içerisinde başta emek piyasası olmak üzere farklı araçlar üzerinden yer değiştirme, hareket etme gereksinimi hep başat bir role sahip olmuştur. Ne var ki, sözkonusu hareket kanalları ne kadar açık olursa olsun genel olarak göç yoksulluğun yeniden üretminde hep belirleyici olma rolünü korumuştur.

$\mathrm{Bu}$ bağlamda kentsel gelişmeler imar kararları ile gelişen formel alanlar ile birlikte göç ve yoksulluğun mekanı olarak kaçak ve niteliksiz konutlardan oluşan ikili bir fiziksel yapı çerçevesinde gelişimlerini sürdürmüşlerdir. Bu yapılanmada göç ve yoksulluk kentsel mekânda enformelliğin kaynağı olmuştur. Burada enformellik her ne kadar fiziksel biçimleniş ve dolayısıyla kaçak olarak üretilen yapılar açısından daha görünür olsa da gerçekte emek ve iş piyasası açısından da kendisini belirgin olarak yer bulmuştur. Tarihsel olarak ortaya çıkmış pek çok araştırmada gerek konut üretim süreçlerinde ve gerekse de emek piyasasında ortaya çıkmış olan bu enformel yapılanmanın giderek formel süreçlerin temel bileşeni olarak çok önemi bir konum kazanmış olduğu tartışılmıştır (Erder, 2013). Bulgular ülkemiz pratiğinde kentleşmenin enformellikten beslendiği yönündedir (Şenyapılı, 1978) ve böyle bir bulgu, sistemin enformel yapılara olan ihtiyacını da ortaya koyduğundan, göçle oluşmuş yaşama alanları açısından devingenlik şartlarının da bu ihtiyaç temelinde tarif edilebilmesi mümkündür. Dolayısıyla yaşam şartlarında ortaya çıkması beklenen iyileşmenin bireylerin ve toplumların çabasından bağımsız bir içerikte daha fazla ekonomik sistem ve işleyişe bağlı açılımları bulunmaktadır.

Konuya kentleşmenin fiziksel gelişimi ve bu bağlamda gecekondulaşma açısından bakıldığında, temel barınma gereksinmeleri çerçevesinde ortaya çıkmış olmakla birlikte böyle bir yapılanmanın taşınmaz piyasası içerisinde kazanmış olduğu ayrıcalıklı konum itibariyle, yer, konum ve giderek sınıf değiştirme aracı olarak konut üretiminin, kentsel yaklaşım ve politikaların temel meselesi haline gelmiş olması şaşırtıcı değildir. Kent planlama stratejileri, her gün yeniden üretilmekte olan mevcut sistemin fiziksel kurgusunu sürekli kılacak araçları üreterek, gerçekte ekonomik işleyişi de bireyler ve toplumlar açısından sürekli kılmaya çalışmaktadır. Bu durum kentsel gelişme kararlarının ekonomi politikaları ile olan yakın bağının ve esasen kentsel politikaların sistemin işleyişini garanti altına almadaki önemli rolünün bir sonucu olup, dönemsel farklılıklar içermektedir. Bu bağlamda sermayenin genişlemesine her zaman imkan sağlayan yenileme uygulamaları, kendisine alan açabildiği kent parçalarında ve özellikle de göçle oluşmuş yoksul yaşama alanlarında farklı yasal düzenlemeler ve stratejiler eşliğinde hayat bulmuştur. 2000'ler sonrası süreçte ise bu uygulamalar kentsel dönüşüm olarak adlandırılan büyük ölçekli yenileme uygulamaları haline gelerek etkinlik kazanırken, üzerinde çokça düşünce geliştirilen ve araştırmaların yapıldığı bir konu başlığı haline de gelmiştir. Kentsel dönüşüm uygulamaları ağırlıkla kendisine göçle oluşmuş yaşama alanlarını hedef seçerken, bu bölgelerde yaşayan toplulukların yaşamlarını da açığa çıkan yeni ekonomi ve fiziksel biçimleniş aracılığıyla önemli ölçüde etkilemeye başlamıştır. Böyle bir etki, göçü her zaman yarattığı emek gücü nedeniyle kentte tutmaya çalışan bağışlayıcı ve yaratılan ekonomik değerden pay vermeye çalışan anlayışın uzantısı olmakla birlikte, daha önce konum ve yarattığı yaşam pratikleri yönünden daha ölçülü olan müdahale biçimlerinden oldukça farklı açılımlar taşımasından kaynaklanmaktadır. İçerdiği bu farklı tutum ve ortaya çıkardığ $1 /$ çıkarabileceği sorunlar açısından çokça araştırmanın konusu haline gelen kentsel dönüşüm uygulamaları, kentlerdeki devingenlik koşullarını yeniden tarif eden bir yapılanma olarak bu çalışmanın da temel bileşenlerinden biri haline gelmiştir. Sonuç olarak göç kendisini kentsel ortamda var eden ve geliştiren devingenlik kavramı ile birlikte ele alınırken, kentsel dönüşüm de bu ilişkide önemli etkiler yaratan bir kentsel müdahale biçimi olarak bu çalışmanın önemli başlıklarından biri halini almıştır.

Göç olgusu geliştiği aşamalarda devingenliğe dair pek çok çalışmanın üretilmesine zemin hazırlamıştır; bu çalışmalar devingenliği, devingenlik kanallarını, devingenliğin biçim ve özelliklerini inceleyip kavramsallaştırmışlardır. 2000 yılı öncesinde yapılan sözkonusu araştırmalar, göç ve devingenlik ilişkisini odağına mekânsal, toplumsal ve ekonomik devingenliği alarak kurmuştur. 2000'den sonra ise kentsel dönüşümün yasa ve 
mevzuatlarda yer alması kentlerde çeşitli göç ve devingenlik biçimleri yaratmaya başlamış ve göç-devingenlik ilişkisini açıklarken kentsel dönüşüm faktörünün de dikkate alınması gerekliliğine yol açmıştır. Bu doğrultuda 2000 yılından itibaren göç, devingenlik ve kentsel dönüşüm unsurlarının birbiri ile ilişkisinin nasıl kurulduğu bu çalışmanın temel sorusunu oluşturmuştur.

Çalıșma temel olarak kırdan kente göç hareketlerini ve buna paralel olarak kentleşme süreci ve devingenlik hareketlerini ele alan araştırmalara odaklanarak, öncelikle dönemsel değişimler temelinde devingenliğin hangi açılımlarda ele alınmış olduğunu ortaya koymaya çalışmaktadır. Bu çerçevede göç ve devingenlik anahtar kelimelerinde yapılan taramalara ilave olarak kentsel dönüşüm de hem devingenlik şartlarında yarattığ 1 etki, hem de son süreçte artan popülerliği ile kentsel araştırmaların odağında yer almaya başlamış olmasıyla taramalardaki anahtar kavramlardan bir başkası olarak ele alınmaktadır. Bu amaçla çalışma 'Google Scholar' üzerinden Ocak 2000 ve Ekim 2021 tarihleri arasında yapılmış dijital makaleler üzerinden gerçekleştirilmiş ve 'Göç', 'Devingenlik' ve 'Kentsel Dönüşüm' anahtar kelimelerini içeren makale taramaları üzerinden, araştırma başlık ve konularının nasıl değiştiğine bakılarak ortaya çıkan sonuçlara temellendirilmiştir.

\section{Kavramsal İnceleme}

\subsection{Devingenlik}

Türk Dil Kurumu (TDK, 2020) 'nun yaptığı tanıma bakıldığında "hareketlilik" olarak açıklanan devingenlik kavramı, araştırmalarda ele alınış biçimlerine göre incelendiğinde hareketliliğin yanı sıra herhangi bir durum ya da konuda gözlemlenen değişkenlik yani dönüşüm anlamlarında da kullanılmaktadır. Modernleşme süreci ve nüfusun mekandaki yer seçimi olarak nitelendirilen kentleşme dinamikleri (Tekeli, 2015), toplumun kendine yer bulabilmesi için oluşturduğu devingenlik ve devingenlik kanalları çerçevesinde şekillenmektedir. Chicago (Şikago) Okulu yaklaşımları, Castells, Harvey gibi kentleşme için önemli kuramcılar, kenti 'ayrışma ve farklılaşma' nın görüldüğü bir olgu olarak, bahsi geçen gruplaşmalar ve bu gruplaşmaların birbirleri içerisindeki devingenliklerinin kent sistemini oluşturan temel bir unsur olduğunu kabul edilmektedirler (Harvey, 2002; Serter, 2013; Castels, 2017). Kentlerdeki mekanlar, toplumsal yapının katmanlaşmasına bağlı olarak şekil almakta ve bu katmanlaşma hem iş hem de konut piyasasındaki çatışma ve devingenlikle birlikte kentlerin günümüzdeki karmaşık ve çeşitli halini almasina neden olmaktadır (Erder, 2002).

Kent ve kentleşme için bu denli belirleyici bir rol oynayan devingenlik kavramının yer değiştirme çalışmalarına yansıması ise çoğunlukla göç hareketleri sonucu kentlerde ortaya çıkan yoksul alanlardaki iş ve konut piyasası ile toplumsal devingenlik üzerinedir. İş piyasasında; ağırlıkla marjinal sektör, konut piyasasında; enformel konut piyasası, gecekondu ve yoksul konut alanlarında yoğunlaşmaktadır. Bahsedilen konut piyasasının Türkiye'deki sürecine bakıldığında 1980 yılı ve öncesinde 'barınma' amaçlı iken, 1980'lerle birlikte görülmeye başlanan neoliberal politikalar ile barınmadan çıkıp 'ticarileşerek' ekonomik bir olgu olmaya başlamaktadır (Erder, 2013). Anlatılan tüm bu kavramlar kentte var olma ve devingenliğin alt alanlarını içermektedir (Şekil 2).

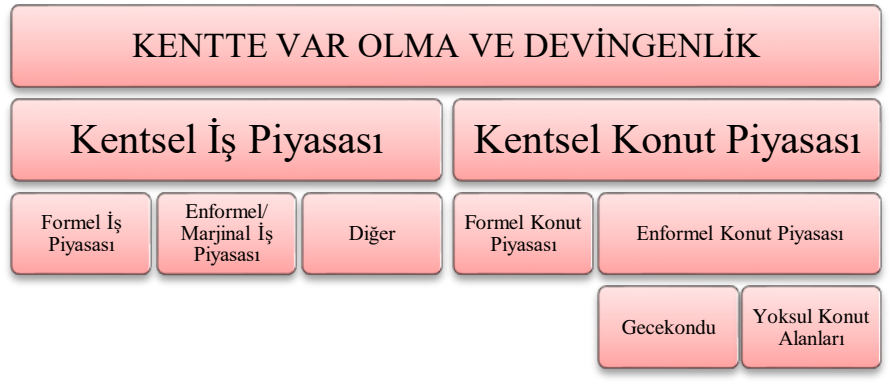

\section{Şekil 1. Kentte Var Olma ve Devingenlik}

Göç sonrası kentte yaşamı sürdürebilmek için öncelikli olarak iş ve konut sorununu çözmek gerekmektedir. Bahsedilen çözüm sürecinde göçmen, konutu gecekondu yoluyla, işi ise marjinal iş piyasası üzerinden yapmaktadır. Hemşerilik ve akrabalık bağları ise bu konuda bir devingenlik yaratarak göçmene de kentte yaşadığı toplumsal sorunlara da yardımcı olmaktadır (Koç, 2012). Söz konusu şartlar açısından kentsel gelişmelerin farklı evreleri farklı olanaklar sunsa da taşınmaz piyasasının kentin yapılanması içerisinde her zaman önemli bir rol üstlenmiş olması, arsa piyasasının da kaçınılmaz olarak devingenlik koşullarının oluşmasındaki temel yönlendiricilerden biri olmasını sağlamıştır. Bu bağlamda kent planlaması farklı kentsel müdahaleler yoluyla ve son süreçte de kentsel dönüşüm uygulamaları aracılığıyla kente göçle gelmiş ve yaşam koşullarını iyileştirerek kentin bir parçası olmaya çalışan topluluklar için yeni hareket olanaklarını oluşturmaktadır. Böylece kır-kent göçünün ilk dönemlerinde coğrafya değiştirmek suretiyle ortaya çıkan devingenlik giderek aynı kentin içinde planlama kararlarının yönlendirdiği bir hareketlilik ve yer değiştirme süreci olarak izlenmeye başlamıştır. Kent planlama stratejileri içerisinde imar afları ile yasallaştırma, imar hakları ile geliştirme ve son süreçte ise kentsel dönüşüm yoluyla yer ve konum değiştirme biçiminde özetlenebilecek müdahale stratejileri ile devingenlik açısından farklı sonuçlar ortaya çıkmıştır. Bu bağlamda kentleşme tarihinin söz konusu devingenlik koşulları yaratan süreçler açısından ve özellikle de kentsel müdahaleler yönünden incelenmesi son derece önemlidir.

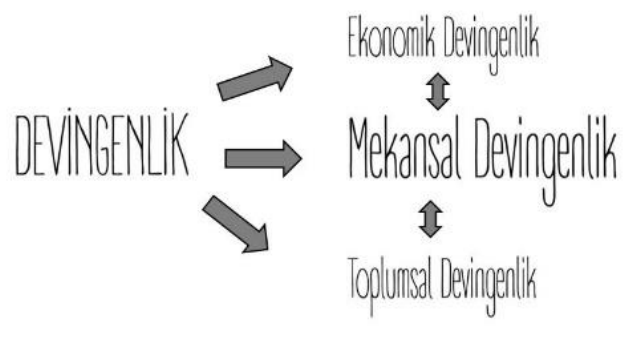

\section{Şekil 2. Devingenliğin Ele Alınma Şekilleri}

Göç sürecini tanımlarken 'yapısal değişme'den bahseden ve bundan dolayı süreci devingenlik ve büyük toplumlar halindeki mekânsal değişme ile bağdaştıran Erder (2013), zamanla ticarileşen gecekondu alanlarının mekânsal devingenliği arttırdığını, bununla birlikte toplum gruplarındaki toplumsal devingenlikte "yaşam döngüsünün" bulunduğunu söylemektedir (Erder, 2013:290). Türkiye'nin göç tarihini incelediğimizde göç hareketlerinden sonra kentsel mekânda görülen yatay devingenliği Sevgi (1988), mekânsal hareketin yanı sıra sosyal ve ekonomik devingenlik olgusunu içeren değişimler olarak tanımlamaktadır. Tüm bu yaklaşımlarla birlikte Şenyapılı (1977) da kentlerde görülen devinim olgusunun sosyo-ekonomik yapının 
mekâna yansıması olduğunu söylerken, hem sosyal hem ekonomik yapılaşmalar arasındaki dönüşümün süregelen bir rekabet içerisinde bulunmasından dolayı mekandaki devingenliğin daha esnek ve değişken bir yer seçimle şekillendiğini ortaya koymaktadır. Ortaya konulan bu yaklaşımlar sonucunda devingenliğin, göç alan kentlerde konut (mekânsal), iş piyasası (ekonomik) ve toplumsal yapı üzerinden ele alındığını söylemek mümkündür (Şekil 3).

\subsubsection{Mekansal Devingenlik}

Mekânsal devingenlik yani konut devingenliğine bakıldığında, kırdan kente olan göç sürecini tamamlamış kişilerin kentsel alandaki konut sunumlarından biri olan gecekondular temelinde devingenliklerini devam ettirdikleri görülmektedir. $\mathrm{Bu}$ sadece kente ilk gelindiğinde seçilen yer olmayıp, süreç içerisinde kent içerisindeki farklı bölgelere doğru kaymaları da kapsamaktadır. Bu sürece bakıldığında İstanbul ve diğer büyük kentlerin halihazırda bulunan kozmopolit ve devingen yapısına göçle birlikte farklı konut sunumlarının da eklendiği görülmektedir (Epli İşler, 2010). İlk dönem göçler için Ersoy (1991)'un Ankara'daki bir çalışmasında göç sonrası ilk yerleşilen mahallelerde kalma süresi ortalama 12 yıl iken, bunun sonraki dönemlerde 2 yıla kadar indiğini belirtmiştir. Süreç içerisinde yaşanan kent içi mekânsal devingenliğin artmasının ise benzer özellikteki konut sayısının artmış olması, iş alanlarının kent içerisinde yayılmış olması ve ilk dönem toplumsal ilişkiler ağının zayıflaması olduğunu ileri sürmüştür. 1980 sonrasında ise benzer mahalleler arasında yaşanan bu yer değiştirmeler küreselleşme ile birlikte kentlerde artan rekabetlerin sonucunda kentsel alanlar değer kazanmıştır. Bunun sonucunda ise hem mahallerin niteliğinin değişmesine hem de benzer yerlerden farklı olarak yeni alanlara geçişin olmasına neden olmuştur. Ortaya çıkan bu yeni değerle birlikte kent merkezlerine yakın konumlanan göçle oluşmuş gecekondu alanları da hem ekonomik hem toplumsal devingenliğe uğramıştır. Kentsel dönüşüm araçlarıyla yaşanan söz konusu alanlardaki bu değişimde metropollerdeki fiziksel eşiklere dayanmış olmasından kaynaklı büyüme sorunu ve sermayede yaşanan birikim krizlerinin aşılmasında kentsel arsa rantının kullanılması yatmaktadır. Bu nedenler yatırım maliyetleri açısından yüksek olan dezavantajlı grupların konut stoklarının rezidans gibi üst gelir grubu konut sunum biçimleri ile yer değiştirmesini ortaya çıkarmıştır (Göksu ve Bal, 2010).

Küreselleşme kentsel alanlarda değer yaratma koşullarını değiştirirken, göçle oluşmuş ve kent merkezine yakın gecekondu alanlarındaki hareketlilik artmıştır. Bu çerçevede açığa çıkan yer değiştirme hareketleri bir yandan kentleşmenin sürecinin doğurduğu bir durum olarak tanımlanırken, bir diğer yandan kentsel alanda "rantın gaspı" (Erder, 2001) olarak da adlandırılmaktadır. Birbirinden ayrı tanımlamalar kullanılmış olsa da en nihayetinde bahsedilen değişiklikler sonucunda gecekondu alanlarında yaşayan toplumun ekonomik koşullarında devingenlikler ortaya çıkmaktadır. Kentlerde görülen gecekondu alanları, göç sonucu ortaya çıkan ekonomik, mekânsal ve toplamsal üç temel sorundan biri olan mekânsal devingenliğin bir çözümü olarak karşımıza çıkmaktadır. Şenyapılı bahsedilen bu çözümü ekonomik hareketliliğin mekandaki yansıması olarak yorumlamakta ve bu alanlardaki devinimin göçerlerin ekonomik koşulları doğrultusunda şekillendiğini söylemektedir. Kısacası ekonomik gelir arttıkça gecekonduların yapısal durumu da bununla orantılı olarak iyileşecektir (Şenyapılı Ö, 1981; Erder, 2001; Kizilay, 2016).

\subsubsection{Ekonomik Devingenlik}

Bir diğer devingenlik konusu ekonomik iş piyasasıdır. Ekonomik piyasadaki ilişkiler, toplumsal ve mekânsal unsurların biçimlenişini etkilemektedir. $\mathrm{Bu}$ da bir yandan göçle gelen toplumsal grubu ilgilendiren bir durumken diğer yandan kentteki yerleşik düzenle de ilişkilidir (Şenyapılı T, 1981). Kente göçle gelenler, var oluş mücadelesi içerisinde kentteki tüm kaynakları kullanma çabasına girmektedir. Bu da emek ve konut piyasasında devingenliğe ve kitlesel mekânsal değişimlere yol açarken (Erder, 2013), ekonomik koşullarda meydana gelen değişiklikler sonucunda görülen yer değiştirmelerle toplumsal olarak da hareketliliğe neden olabilmektedir. Özellikle göç sonrası örgütsüz, ucuz, esnek iş gücünün barınma alanı olan bu yapı içerisinde ilişki ağları arasında iş piyasasındaki devingenlik kanalları, hangi göçmenin hangi piyasa içerisinde olacağını belirlemektedir (Çetin, 2010; Kızılay, 2016). Şenyapılı (1977)'nın çalışmasında göç sonrası marjinal sektörler hakkındaki tespiti, göçmenlerin inşaat, küçük ticaret ve imalat, büyük ticaret ve imalat ile hizmet sektörü olduğunu belirlemiştir. Kadığ lu Ateş ve Adam (2016) ise 'iş değiştirme ve devingenlik' üzerine yaptıkları çalışmada bunu genellikle sıklıkla değiştiğini tespit etmiştir. Kentlerde var olan istihdam, gelir düzeyini yükseltme olanaklarının varlığı mevcut hayat standartlarını yükseltmesi için bir firsat yarattığı için önemlidir ve bunlara ulaşabilmek için var olan devingenlik kanallarını kullanmaktadır (Günaydın, 2015).

Özellikle 1980'li y1llardan sonra ortaya çıkan neoliberal politikalarla birlikte kentlerdeki ekonomik politikalar ve buna bağlı mekânsal dağılımlar farklılaşmaya başlamıştır. $\mathrm{Bu}$ da kentlerde ekonomik temelli mekânsal ayrışmaların ortaya çıkmasına, kentlerde “gettolaşma” "nın görülmesine yol açmıştır (s.125). Yeni liberal politikalar birlikte hızlanan kentleşmede formel üretimin yetersiz kalması, buna alternatif olarak enformel sektörün ortaya çıkmasına yol açmıştır. Önceleri hemşehrilik ilişkilerinin şekillendirdiği göçle gelen yoksul topluluklar, 1980'lerden sonra enformel iş sektörü ağ ile şekillenmeye ve bu ağ çerçevesinde devingenlik göstermeye başlamıştır (Ünverdi, 2002).

\subsubsection{Toplumsal Devingenlik}

Toplumsal devingenliği "kişi ya da grupların hiyerarşik toplumsal yapı içerisindeki bir konumdan diğerine geçişleri" olarak tanımlayan Tüzün (1982)'e göre devingenlik yatay ve dikey olarak ele alınabilmekte ve bunun en büyük etmeninin ekonomi ve iş piyasası olduğunu savunmaktadır. Kısaca kişi veya grupların halihazırdaki toplumsal konumundan bir başka toplumsal yapı içerisine geçmesi olarak tanımlanabilen toplumsal devingenlik kavramı, iş, meslek, sınıf farklılıkları, ekonomik statü olarak farklı konularda ele alınabilmektedir (Tüzün, 1982: 173) (Şekil 4). Kentler incelendiğinde üretim ilişkileri sadece mekânı değil aynı zamanda mekandaki toplumsal ilişkileri de üretmektedir (Ünal, 2016). Kentteki her türlü kaynaktan beslenmeye çalışan gecekonduluların yoksulluktan kurtularak hatta zenginleşerek kendi yoksulluklarını devretmesi ve yeni gelenin de aynı koşulları sağlayabilme umuduna sahip olması olarak nitelendirilirken, bu süreç kültürel ve ekonomik unsurların karş1lıklı etkileşimini de içermektedir (Çetin, 2010; Işık ve Pınarcıoğlu, 2018). Buradan da anlaşılacağı üzere bu karşılıklı etkileşim kentte mekânsalla birlikte toplumsal ve ekonomik devingenliğe yol açmakta ve kentle birlikte değişen gecekondu alanları heterojen bir alan oluşturmaktadır (Erder, 2001). Esasında göç mekânsal bir hareket olması ile birlikte önemli bir toplumsal devingenlik yaratmaktadır (Tümtaş ve Ergun, 2016). Said'den 
aktaran Günaydın (2015) göçü "kesintili bir var olma durumu olup geride bırakılan yerle bir kavgaya tutuşma biçimidir" şeklinde tanımlamaktadır. Kentlerde göç sonrası yer seçiminin ve kent içerisi devingenliğin önemli belirleyicilerinden olan hemşeri ilişkileri bir arada olmanın ve sonraki dönemlerde görülen örnekleri ile toplumsal ilişki ağlarının etkisinin zayıflamasının toplumsal devinginlik üzerinde etkisi bulunmaktadır (Ersoy, 1991).

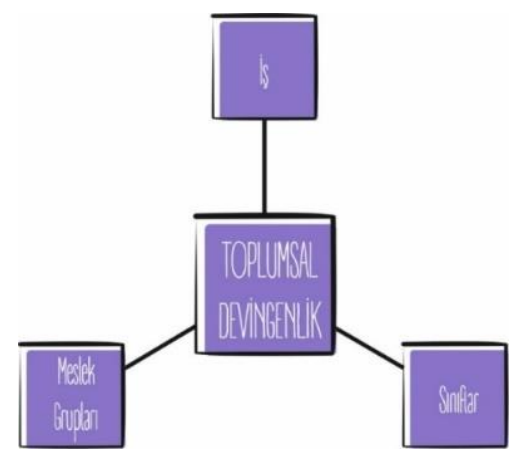

Şekil 3. Toplumsal Devingenliği Etkileyen Faktörler

\subsection{Devingenlik -Göç İlişkisi}

Göç kavramının tanımına bakıldığında; insanların belirli zamanda bir yerden başka bir yere geçmesi olarak tanımlansa da aslında belirli neden ve sonuçlara göre şekillenen bir olgu olarak karşımıza çıkmakta (İçduygu ve Sirkeci, 1999), bir yandan mevzuat gelişimini etkilerken bir diğer yandan mevzuat tarafından şekillendirilen çok yönlü bir süreç olmaktadır. Süreç içerisinde farklılıklar gösteren göç hareketlerinin sonucundaki genel mekânsal ve toplumsal yansımalar (Güreşçi, 2010);

- Kentte oluşan mekânsal dokunun dönüşümü,

- Kirdan kente gelen toplum grubunda yaşanan kimlik değişimi ve bu süreçte ortaya çıkan çatışmalar,

- Göçle gelen toplumun kentlilerle kurduğu iletişimdeki değişimler ve bu değişimlerin kentte yarattığ 1 etkileri,

- Tarımsal alanlar başta olmak üzere köylerde gözlemlenen fiziksel ve demografik değişimler,

- Bu süreçte hala kırsalda kalmayı tercih eden kişilerin, göç eden toplumla çatışması ve onlardan beklentileri, ç1kması,

- Kırdan gelen göçler sonucu kentlerde köy gruplarının ortaya

- Göçerlerle birlikte nüfusun artması sonucu, kentlerde öngörülen kişi başına düşen hizmet ve yatırım maliyetlerinin yetersiz kalması ve bu yüzden altyapı ve sosyal donatıların yetersiz olması olarak özetlenebilmektedir.

Tüm bu sayılanlarla birlikte göç hareketleri mekânsal bir yer değiştirme değil, ayrıca kültürel, toplumsal ve ekonomik bir hareketliliktir (Çetin, 2010). Kentler sanayileşme sonrasında işte ihtisaslaşma ve rekabetin artması ile birlikte özel mülkiyet bağlarının da şekillendirdiği kentleşme kavramıla birlikte anılmaya başlamaktadır. Bu yüzden göçün ortaya çıkardığı kent biçimi tanımlanmaya çalışılırken, ekonomik bir zemin üzerine kurulmuş kültürel ve toplumsal bir yapılaşma ve bu yapılaşma içerisindeki süregelen devingenlik de beraberinde incelenmelidir (Geniş \& Köse Akkirman, 2020; Lefebre, 2017).

Henüz tam olarak tanımlanamadığı düşünülen kentleşme süreci sadece nüfusla belirlenememekte (Wirth, 2002), biriken sermaye sonucu ortaya çıkan toplumsal yapılaşma bu süreci biçimlendiren en önemli etmenlerden biri olmaktadır (Harvey, 2015). Bu yüzden kentleşmenin sermaye-emek ilişkisi ve bu ilişkinin ortaya çıkardığı sınıfsal yapılarla birlikte ele alınması gerekmektedir. (Harvey, 2002). Kentleşmenin önemli parametrelerinden biri olan göç; 1930'larda başlayıp 2. Dünya Savaşı sonrasında uygulanan sanayi planlarıyla artış göstermiştir (Çetin, 2010; Özden, 2016). Sanayileşmeyle birlikte kentlerde ortaya çıkan işgücü açığını kapatma amaçlı başlayan kırdan kente göç hareketleri başlarda önemsenmezken, sonraları kontrol altına alınamamasıyla birlikte kentlerde büyük toplumsal, mekânsal ve ekonomik devingenliklere yol açmıştır (Davis, 2010). Ulus devlet sonucu kırdan kente göç alan kentlerdeki yer seçmelerle farklı sektörlerde çalışma amacı görülmüş ve bu da gecekondunun altyapısını hazırlamıştır (Çetin, 2010; Özden, 2016; Erdoğan 2020).

Göçün bir sonucu olarak ortaya çıkan gecekondu ve onun barındırdığı nüfus kentle bütünleşme sürecinde devingen bir yap1 içerisindedir. Ersoy'un (1994) 1981 ve 1991 yıllarında yapılan iki farklı çalışmadan aktardığına göre bu nüfus mahalleler arası devingenlik içerisindedir. Her yeni gecekondu, yapıldığı kentsel alanı ve aflarla birlikte götürülen hizmetlerle planları olmasa dahi birer konut bölgesi haline getirmektedir. Bu alanlar zamanla ve konumuna göre mekânsal olarak farklılaşırken, ranttan alınan payın da etkisiyle bahsedilen alanların sosyo-ekonomik yapısı da değişmektedir. $\mathrm{Bu}$ değişimler sırasında bulundukları alanlarda varlıklarını sürdüremeyenler ise yeni bir yerleşim yerine doğru hareket etmektedir. Kapitalizmin gelişiminin göçmen kitlesinin homojenliği üzerinde yarattığı etki ile olan bu durum (Ersoy, 1994), göçmenlerin tercihleri ile de şekillenmektedir. Süreç içerisinde sermayenin tercihleri ile birlikte farklı dönemlerde çıkan yasa ve verilen haklarla birlikte değişmeye başlayan alanların yeniden düzenlenmesi 2000'li yıllardan sonra yasallaşan kentsel dönüşüm uygulamaları ile gerçekleşmeye başlamıştır.

\subsection{Devingenlik - Kentsel Dönüşüm İlişskisi}

Türk Dil Kurumu (TDK, 2020) tarafindan "imar ve yap1 kanunlarına aykırı olarak başkalarına veya kamuya ait arazi veya arsalar üzerinde toprak sahibinin bilgisi ve rızası olmaksızın acele yapılmış konut, kondu" ve "acele ile yapılıvermiş, derme çatma yapı" gibi tanımlamalarla anılan gecekondu, göçle ortaya çıkmış ve kentsel alanda zaman içerisinde farklılık göstererek önemli bir konut sunum biçimi halini almıştır (Ağın, Tezcan, ve Zengin Çelik, 2018). Şehirlerdeki iş merkezlerine yakın olan alanlarda ya da yerleşimin pek de uygun olmadığı sanayi alanlarının kenarları, dere yatağı ya da tepe gibi dezavantajlı yerlerde ortaya çıkmaya başlayan ilk gecekondu alanları, süreç içerisinde kentin etrafinı saran halkalar şeklinde büyümeye başlamıştır (Tezcan ve Zengin Çelik, 2017). Başlarda görülen uydu kentler gibi yeni kentsel planlama yaklaşımlarından dolayı kentli toplumun çeperlere doğru yönelmesi ve merkezin âtıl kalmaya başlaması ile gecekondu alanlarının merkezde yer seçmesi kolaylaşmıştır. Sonraları ise küreselleşme ve kentlerde görülmeye başlayan rekabetlerle birlikte kent merkezi tekrar değer kazanmaya başlamış, bu da gecekondu bölgelerinin kentler için birer sorun halini almasına neden olmuştur. Esasında tüm bu göç ve kentsel alanlardaki değişkenlik fizyolojik ve sosyolojik anlamda yeni gereksinimler ortaya çıkaracağından bu yeni durum ve ihtiyaçlara göre kentlerde nüfusun devingenliği çerçevesinde yeniden yerleşimler oluşacaktır (T.C. Bayındırlık ve İskân Bakanlığı, 2009). 
Cumhuriyet'in ilanından itibaren günümüze kadar çıkartılan ve kentleşmeyi etkileyen yasal düzenlemeler göçün de kırılma noktaları göz önünde bulundurularak 1923-1950 arası, 1950-1980 arası, 1980-2000 arası ve 2000 yılı ve sonrası olmak üzere dört ayrı dönemde ele alındığında, en fazla yasal düzenlemenin 2000 yılı ve sonrası yapıldığı görülmektedir. $\mathrm{Bu}$ yasaların özellikle 2004 y1lından itibaren "kentsel dönüşüm" olarak kavramsallaştırılan büyük kentsel müdahaleler ile ilgili olduğu görülmektedir (İçduygu \& Sirkeci, 1999; Tekeli, 2016; Özden, 2016; Tezcan \& Zengin Çelik, 2017; T.C. Cumhurbaşkanlığ 2020). İlk olarak 2004 yılında 5104 sayılı Kuzey Ankara Kentsel Dönüşüm Kanunu'nun çıkartılmasıyla başlayan bu sürecin devamında, mevzuatta çeşitli düzenlemeler yapılmaya başlanmıştır. 2005 yılında belediyelere kentsel dönüşüm yapma hakkı tanınmış, 2005 ve 2006 yıllarında sonraki dönemlerde çıkartılacak olan kentsel dönüşüm yasalarına ilişkin yasa tasarıları oluşturulmaya başlanmıştır. Bunun devamında ise 2010 yılında 5393 sayıl1 'Belediye Kanunu'nun 73. Maddesi' ile Belediyelere, 2012 yılında 6306 sayılı 'Afet Riski Altındaki Alanların Dönüştürülmesi Hakkında Kanunla’ Çevre, Şehircilik ve İklim Bakanlığı'na dönüşüm yapma yetkileri verilmiştir. Bu dönemden sonra sirasıyla 2013, 2015, 2016 ve 2017 bahsi geçen kanunlarla yapılan kentsel dönüşüm müdahalelerinin en fazla uygulandığı y1llar olmaktadır (Tezcan, 2020a; Tezcan 2020b). Bu aşamadan sonra uygulamaların önceki dönemlere oranla daha büyük alanları hedef alarak ve tek seferde ya da etaplar halinde gerçekleşen yıkım çalışmaları ile ortaya çıktığı izlenirken, bu uygulamaların gerçekleşmesi ile alandaki göçmenlerin sahip oldukları tapu ve varlıkları ölçüsünde yeni bir yer değiştirme sürecinin içine girmeleri de kaçınımaz hale gelmeye başlamıştır. "Hane halkının bir ikamet adresinden bir diğerine olan kısa mesafeli hareketi" olarak tanımlanabilecek bu kent içi hareketlilik (Özgür ve Yasak, 2009:40), kentsel dönüşüm uygulaması yapılan bölgelerde sıklıkla görülen bir durum halindedir ve sadece mekânsal olmayıp, aynı zamanda toplumsal bir hareketlilik olarak da gündeme gelmektedir. Bu durum büyük ölçüde göçle oluşmuş yaşama alanlarında ya yoksulluk şartlarındaki bireylerin yeni sürecin yarattığı ekonomiyi göğüsleyememeleri ile ve yine yasal koşulların sağlanamaması ya da yeni fiziksel çevreye adapte olunamaması gibi sebeplerle de gerçekleşebilmektedir. Diğer yandan kentsel dönüşüm özellikle kentte uzun süredir yaşayan ve yasal süreçlere dahil olmayı başarmış bazı kesimler için, kentsel ranttan pay almanın bir aracı olarak da önem kazanmaktadır. Bütün bunlarla birlikte aileler enformelliği özellikle de çalışma koşulları çerçevesinde sürdürebilecekleri yeni yoksul mahallelere taşınarak sürdürmeyi de seçebilmektedirler.

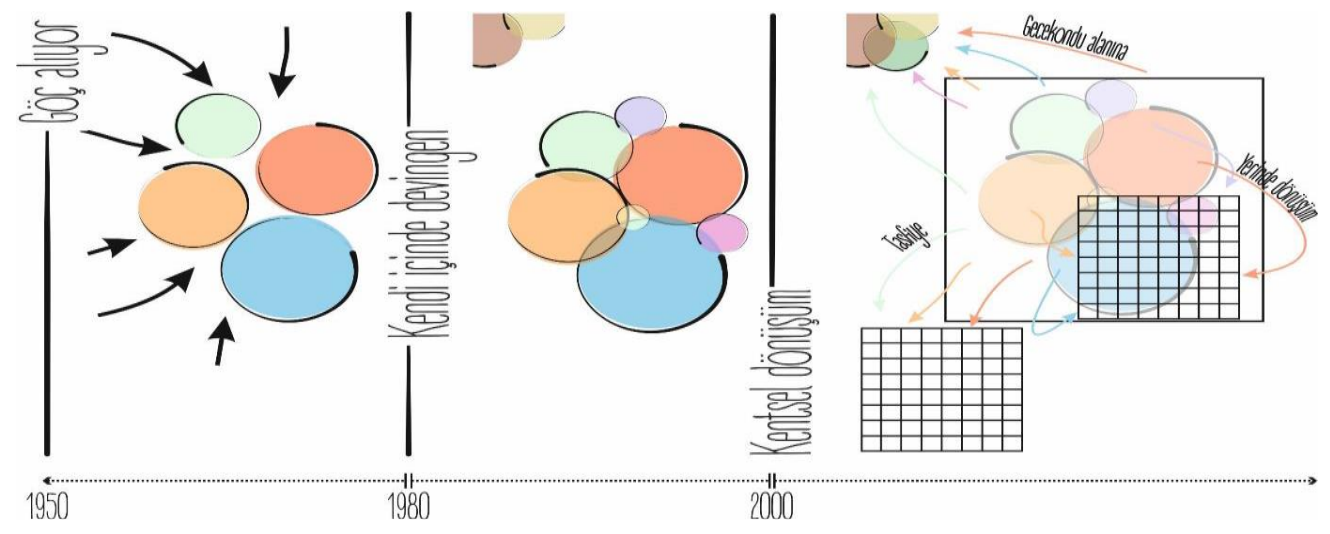

Şekil 4. Kentsel Dönüşüm Uygulaması Sonucu Devingenlik Örneği

Dolayısıyla 2000 yılı sonrasına bakıldığında göçle oluşmuş iç içe geçmiş karmaşık toplum gruplarının bulunduğu alanlarda yasalar yoluyla uygulanan büyük alansal yenileme ve dönüşüm müdahalelerinin farklı devingenlik kanalları açısından önemli sonuçlarının olduğunu söylemek mümkündür. $\mathrm{Bu}$ durum Kentlerde hemşerilik ve akrabalık ilişkileri kanalıyla şekillenen küçük toplumsal gruplaşmaların yoksulluk şartlarının aşılmasında sağladığı kolaylaştırıcı dayanışma ilişkilerini zayıflatan bir içerik yaratıyor olması kritiktir. Diğer yandan 1980'lerden itibaren kentlerde şekillenen kimlik temelli yapılanmaların doğasını da yeniden biçimlendireceğini düşündürmektedir. Sonuçları henüz yeterince izlenemese de, bu gelişmelerin sınıfsal ayrışmayı keskinleştirme potansiyeli taşıdığı ve bu müdahalelerin yoksulluğu yeni alanlara taşıyı ötelemesi ile kentlerdeki sınıfsal ayrışma desenini de yeniden şekillendirmekte olduğu açıktır (Şekil 5).

$\mathrm{Bu}$ noktada önemli olan ise, devingenliğin tarihsel olarak Türkiye kentleşme pratiği içerisinde ağırlıkla göç, yoksulluk ve beraberinde kentsel yapılarda ortaya çıkan sınıflı toplum yapısı temelinde emek süreçlerinden başlayarak, ekonomik, mekânsal, kültürel ve toplumsal ilişkiler bağlamında bir hareketlilik olarak yaşanıyor olmasıdır. Bu durum, kaçınılmaz olarak devingenliği göçle birlikte ele alınması gerekli bir kavram haline getirmektedr.
Öte yandan ülkemiz koşullarında göçle şekillenen bir kentsel yapılanmanın varlığı böyle bir yapılanmayı şekillendirmeye yönelik mekânsal müdahalelerin temel aktörü olan planlamayı da beraberinde ele alma zorunluluğunu ortaya çıkarmaktadır. Kent planlamanın göçle oluşmuş yaşama alanları üzerinde kırdan kente göçlerin başladığı aşamadan itibaren önemli stratejileri olduğu ve gerek mevzuat ve gerekse de doğrudan plan kararları ile bu alanlarda önemli dönüşümler meydana getirdiği bilinmektedir. Af, ıslah, yeni imar hakları ile sürekli olarak yeniden şekillenen bu alanlarda yaşayan topluluklar emek piyasasının izin verdiği çerçevede sınıfsal konumlarını ve bağlantılı biçimde kent içindeki konumlarını değiştirme olanağı bulurken, 2000'lerdeki kentsel dönüşüm uygulamaları ile devingenlik yaratan koşullar, arsa piyasası ve projeler üzerinden, bu kez emek süreçlerinden bağımsız bir biçimde önemli yapısal değişimler yaratacak bir içerikte gündeme gelmiştir. Ortaya koyduğu etkiler açısından bakıldığında, genellikle ani şoklar biçiminde ortaya çıktığ izlenen karar ve uygulamaların bazı kesimler için belirli pazarlık süreçlerinin ardından kentsel sermayeden pay almak, kentli olmak, bir apartmanda yaşamak gibi devingenlik koşullarını geliştiren, bununla birlikte bazı kesimler için ise yoksulluğu üretecek başka alanlara süpürülmek biçiminde devingenlik koşullarını negatif yönde etkileyen koşulları yaratmıştır. Bu noktadan hareketle çalışmada devingenliğin göç temelinde dönemsel olarak hangi bağlamda araştırmalara konu edildiği 
değerlendirilirken, aynı zamanda bu kavramın kentsel dönüşüm ve bu bağlamda son süreçte izlenen yaygın ve ölçek değiştirmiş kentsel dönüşüm uygulamalarıyla olan ilişkisi açısından da bir inceleme yapılmaya çalışılmıştır.

\section{Araştırmanın Tasarımı ve Yöntem}

Bu çalışmada cevaplanmak istenen sorular doğrultusunda çalışmalardaki kavramların nasıl ele alındığı konusu önemli olduğu için, yanıt aranırken ağırlıklı olarak nitel inceleme yöntemleri kullanılmıştır. Ancak bahsedilen bu nitel içerik incelemelerinin yanı sıra çalışmalarda dikkat çeken veriler de sayı ve yoğunluklarla belirtilerek karşılaştırmalar yapılmıştır.

Cumhuriyetin ilanından itibaren kentlerde değişikliklere neden olan göç hareketleri ve bu hareketlerin ardından ortaya çıkan devingenlik değişkenlerinin yanında, üçüncü bir anahtar kelime olan kentsel dönüşüm uygulamalarının 2000'li yılların başlarından itibaren kanun ve yasalarla tam anlamıyla planlama literatürüne girmesi ve özellikle 2004, 2005, 2006, 2010 ve 2012 yıllarında yapılan yasal düzenlemelerin yansımasını bütünüyle görebilmek adına çalışmalar incelenirken 2000 yılından günümüze kadar olan tüm bu süreç dikkate alınmıştır.

Bu doğrultuda 2000 ile günümüz olan 2021 arasındaki çalışmalarda devingenliğin hem göç hem de kentsel dönüşümle nasıl ilişkilendirildiği yapılmış taramalar üzerinden irdelenmiştir. Tüm bu amaçla 'Google Scholar' üzerinden Ocak 2000 yılı ile 2021 yılı Ekim ayı arasında 'Göç', 'Devingenlik' ve 'Kentsel Dönüşüm' anahtar kelimeleri ile tarama yapılmış ve çalışmalarında bu kavramların üçünü de içeren, çeşitli indekslerce taranan dergilerde yayınlanmış Türkçe toplam 16 dijital makaleye ulaşılmıştır (Tablo 1).

\section{Tablo 1. Göç, Kentsel Dönüşüm ve Devingenlik Anahtar Kelimeleriyle Yapılan Tarama Sonuçları}

\begin{tabular}{l|c|c|c|c|c|c|c|c|c|c}
\hline \multirow{2}{*}{$\begin{array}{l}\text { Çalışmalarda } \\
\text { 'Devingenlik' }\end{array}$} & \multicolumn{10}{c}{ Çalışmanın yapıldı̆̆ yıl } \\
\cline { 2 - 12 } & $\mathbf{2 0 0 5}$ & $\mathbf{2 0 0 6}$ & $\mathbf{2 0 1 0}$ & $\mathbf{2 0 1 1}$ & $\mathbf{2 0 1 4}$ & $\mathbf{2 0 1 5}$ & $\mathbf{2 0 1 6}$ & $\mathbf{2 0 1 8}$ & $\mathbf{2 0 1 9}$ & Toplam \\
\hline Kaynak & 1 & 0 & 1 & 0 & 0 & 1 & 0 & 0 & 0 & $\mathbf{3}$ \\
\hline Metin & 0 & 0 & 0 & 0 & 1 & 3 & 3 & 2 & 1 & $\mathbf{1 0}$ \\
\hline Özet & 0 & 1 & 0 & 1 & 0 & 0 & 0 & 0 & 1 & $\mathbf{3}$ \\
\hline Toplam & $\mathbf{1}$ & $\mathbf{1}$ & $\mathbf{1}$ & $\mathbf{1}$ & $\mathbf{1}$ & $\mathbf{4}$ & $\mathbf{3}$ & $\mathbf{2}$ & $\mathbf{2}$ & $\mathbf{1 6}$ \\
\hline
\end{tabular}

Kaynak: Googlescholar, 2021

Bulunan makaleler incelenirken çalışmalar özet, metin içi ve kaynaklar olmak üzere üç bölüme ayrılmış ve kavramların bu üç bölümden hangisine dahil olduğu belirlenmiştir. Buna göre çalışmanın kilit noktası olan 'devingenlik' konusuna metin içerisinde yer veren çalışmalar incelenmeye devam edilmiştir. $\mathrm{Bu}$ sebeple toplam 16 makale tespit edilmesine rağmen, 'devingenlik' konusuna sadece özet ve/veya kaynakta yer veren 6 makale çalışmadan çıkartılmış, çalışmaya 10 makale ile devam edilmiştir (Şekil 1).

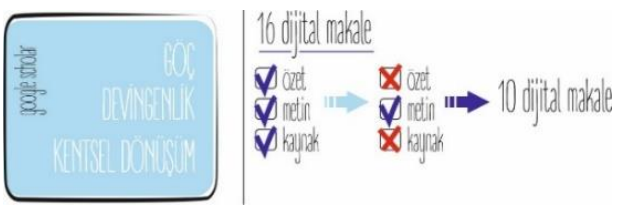

Şekil 5. Araştırma Yöntemi

Belirlenen amaç doğrultusunda çalışmalar incelenirken şu basamaklar izlenmiştir;
* Belirlenen makalelerin, öncelikle içerikleri ve çalışma konularının neler olduğu ve "devingenlik" olgusunu nasıl ele aldıklarına bakılmıştır. $\mathrm{Bu}$ incelemeler yapılırken devingenlik olgusunun, literatürde yer aldığı şekliyle toplumsal devingenlik, mekânsal devingenlik ve ekonomik devingenlik olmak üzere üç gruptan hangisinin içerisinde yer aldığ 1 da tespit edilmeye çalış1lmıştır (Ek 1).

* Konuları ve ele alışları tespit edilen çalışmaların, temel amaçları doğrultusunda yanıtlamaya çalıştıkları hipotez kavramlarının neler olduğu ve bu kavramların hangi yıllarda ele alındığg incelenmiştir. Araştırmalarda ortaya konulmaya çalışılan hipotezlerde yer alan ve ulaşılmak istenen kavramlar tespit edilerek, çalışmaların hipotezleri özetlenmeye çalışılmıştır. Genellikle akademik çalışmalar, ülke ya da dünya genelinde olan güncel konularla paralel şekilde ilerlediği için hipotez kavramları ve yıl ilişkisi ile Türkiye kentleşmesi ve incelenen konuların paralellik gösterip göstermediği açıklanmak istenilmiştir (Tablo 2).

* Yapılan çalışmaların yöntemleri incelenmiş, literatür ya da kaynak taraması, uygulanan projelerin incelenmesi ya da alan özelinde yapılan çalışma olmak üzere ayrılabilen üç farklı yöntemden hangisinin tercih edildiği belirlenmiştir. Buna göre çalışmaların kavramlara hangi açılardan yaklaşmaya çalıştığ anlaşılmaya çalışılmıştır (Şekil 6).

* Bir sonraki adım olarak Ek 1, Tablo 2 ve Şekil 6'da belirlenen bazı bilgiler çaprazlanarak; devingenlik türlerine göre gruplanan çalışmaların (Ek 1), ulaşmayı amaçladıkları hipotez konularına (Tablo 2) nasıl bir yöntemle (Şekil 6) yaklaştıkları incelenmiştir. Buna göre çalışmalarda ele alınan hipotezlerin, hangi devingenlik gruplarıyla ilişkilendirildiğinin görülmesi ve bu ilişkinin kullanılan yönteme bağlı olarak ne kadar derine inilerek kurulmaya çalışıldığına dair fikirler ortaya konulmuştur (Tablo 3).

* Tüm bu makale amaç ve içeriği, hipotez ve yöntem incelemeleri yapıldıktan sonra, çalışmalarda ne tür kavramların ortaya konulduğunun tespiti için, bir diğer önemli unsur olan bulgular da incelemelere dahil edilmiştir. Çalışmaların sonuç ve değerlendirme bölümlerinden elde edilen kavramların, başta ortaya koymaya çalıştıkları hipotezlerle ilişkilendirilmesiyle yapılan bu inceleme, makale çalışmalarının hangi konulara 1 şı tuttuğunun anlaşılmasını sağlarken, aynı zamanda birbiri ile ilişkili olduğu düşünülen 'göç, devingenlik ve kentsel dönüşüm' kavramlarının farklı çalışmalar olsa dahi ne kadar birbiri içerisine geçtiğinin tespit edilmesini sağlamıştır (Tablo 4).

* Tablo 4'te yapılan hipotez ve bulgu karşılaştırmasının sağlamasını yapmak amacıyla çalışmaların her birinde geçen kelimelerin yoğunlukla neler olduğu tespit edilmek istenmiş. Bunun için de tüm bu incelemelerin yanında 'www.wordcounter.net' internet sitesi kullanılarak ayrı ayrı her bir makalede geçen kelimelerin sayılarına yani makalelerin kelime bulutlarına göre kullanım oranları belirlenmiştir (Tablo 5).

*Yine 'www.wordcounter.net' internet sitesinden yararlanılarak makalelerde ortak kullanılan kelimelerin yoğunlukları (Şekil 7) ve on makalenin metinlerinin tek metinmiş gibi ele alınması ile en fazla kullanılan kelimelerin hangileri olduğu tespit edilmiştir (Şekil 8). Bu durum makalelerde ortak kullanılan kelimeler ile on makalenin kelimelerinin bütününe bakıldığında yoğunlukla hangilerinin kullanıldığı arasındaki karşılaştırmayı yapma imkanı sunmuştur. 
* Son olarak da tüm bu incelemelerin genel bir özeti olması düşüncesiyle, neredeyse elde edilen verilerin tamamının çaprazlanarak çakıştırıldığı bir tablo hazırlanarak, devingenlik gruplarına göre bölünen hipotezlerin hangi bulgu kavramlarını içerdikleri, en fazla ortaya konulan bulguların neler olduğu ve bu bulgular özelinde birbiri ile çakışan hipotez ve devingenlik biçiminin olup olmadığı ve varsa neler olduğu net bir şekilde görülmeye çalışılmıştır (Tablo 6).

Çalışma süresince elde edilen bütün bulgular sonucunda da çalışmanın yapılma amacı olan kavramlar arası ilişkinin nasıl kurulduğu ve günümüz kentleşmesinde de önemli bir konu olan 'devingenlik' konusunun literatürde yer alma biçiminin nasıl olduğu ve olması gerektiğine dair yorum ve öneriler geliştirilmiştir.

\section{Araştırma Bulguları ve Tartışma}

'Devingenlik' kavramı her bir çalışmanın konusunu doğrudan etkilerken, yapılan çalışmalara bakıldığında genel olarak göç ve kentsel dönüşüm etkileşiminden bahsederken toplumda, mekânda ve ekonomide ortaya çıkan devingenlik durumu ile ilgili literatür kısmında yer verilmektedir (Ek 1). Çalışmalar göç ve bu süreçle birlikte başlayan devingenlik unsurunun ilişkisini teorik olarak kursa da bu iki unsur ve bunları tetikleyen kentsel dönüşüm uygulamalarının devingenlikle nasıl bir etkileşim içerisinde olduğu sorusu yanıtsız kalmaktadır.

Tablo 2. Çalışmaların İncelediği Kavramların (Hipotezlerin) Yıllara Göre Dă̆llımı

\begin{tabular}{|c|c|c|}
\hline $\begin{array}{l}\text { Çalışma } \\
\text { Yılı } \\
\end{array}$ & $\begin{array}{c}\text { Çalışmanın Hipotezindeki Temel } \\
\text { Kavramlar } \\
\end{array}$ & $\begin{array}{c}\text { Çalışma } \\
\text { Sayısı } \\
\end{array}$ \\
\hline \multirow{2}{*}{2014} & Maddi Kültür - Devingenlik (M9) & 1 \\
\hline & $\begin{array}{ll}\text { Toplam } \\
\end{array}$ & 1 \\
\hline \multirow{4}{*}{2015} & $G \ddot{o c ̧}-S u c ̧(M 6)$ & 1 \\
\hline & $\begin{array}{l}\text { Kentsel Dönüşüm - Kent İ̧ci Göç } \\
(M 3)\end{array}$ & 1 \\
\hline & Yoksulluk-Yönetim (M7) & 1 \\
\hline & Toplam & 3 \\
\hline \multirow{4}{*}{2016} & Göç-Ayrışma (M8) & 1 \\
\hline & Kentsel Dönüşüm - Katılım (M1) & 1 \\
\hline & Küreselleşme - Ayrlşma (M5) & 1 \\
\hline & Toplam & 3 \\
\hline \multirow{3}{*}{2018} & Kentsel Dönüşüm - Gecekondu (M4) & 1 \\
\hline & Kentsel Dönüşüm - Rant (M2) & 1 \\
\hline & $\begin{array}{rr}\text { Toplam } \\
\end{array}$ & 2 \\
\hline \multirow{2}{*}{2019} & Kent Tarihi - Kentsel Siyaset (M10) & 1 \\
\hline & $\begin{aligned} \text { Toplam } \\
\end{aligned}$ & 1 \\
\hline
\end{tabular}

Araştırmaların hangi soruya cevap aramak için yapıldığ incelenirken, hipotezlerinden de yola çıkarak temelde ulaşmak istediği kavramlar tespit edilmeye çalışılmıştır. Hipotezler incelenirken birbiri ile ilişkilendirilen kavramlar dikkate alınmış, belirlenen iki kavram ile hipotezler özetlenmeye çalışılmıştır. Bahsedilen bu kavramların yıllar içerisindeki dağılımına bakıldığında 2014 yılında göç sonucu ortaya çıkan toplumsal 'devingenlik' kavramıyla “maddi kültürr", 2015 yılında 'göç' kavramıyla birlikte 'suç, kentsel dönüşüm, yoksulluk ve yönetim' kavramlarının çalışıldığı görülmektedir. 2016 yılında 'ayrışma/dışlanma' kavramlarıyla birlikte 'göç, kentsel dönüşüm, küreselleşme, katılım'; 2018 yılında 'kentsel dönüşüm, gecekondu ve rant' kavramları üzerinde durulduğu, son olarak ise
2019 yılında 'kent tarihi, kentsel siyaset' kavramlarını temel alan hipotezlere ilişkin çalışmalar yapıldığı ortaya çıkartılmıştır. Bu da gösteriyor ki göç ve bu göçlerle oluşan toplumsal sınıfların kentteki yer alma biçimi ve bu sürecin kentte yol açtığ sorunlarla başlayan ve kentsel dönüşümün uygulanma biçimi ve etkisine kadar uzanan geniş bir çalışma zinciri bulunmaktadır. Ayrıca, 2014 yılında kentsel dönüşüm-göç ve devingenlik ilişkisine dair çalışmaların görülmeye başlanması, günümüzde en önemli kentsel dönüşüm yasalarının çıkartıldığı yıllar olan 2010 ve 2012 yıllarından itibaren yapılmaya başlayan dönüşüm müdahalelerinin etkilerinin görülmeye başlandığı düşüncesini ortaya çıkarmaktadır (Tablo 2).

2014-2019 yılları arasında yapılan çalışmaların süreç içerisindeki konularına bakıldığında; 2014 yılında toplumsal devingenlik ekonomi ile ilişkilendirilirken, 2015-2016 yıllarında göç ve kentsel dönüşüm ilişkisi sıklıkla kurulmuş; göçün süreci olarak suç ve yoksulluk, kentsel dönüşümün süreci olarak küreselleşme, katılım ve ayrışma konuları incelenmiştir. 2018 yılında çalışmalar gecekondu alanlarında uygulanan kentsel dönüşüm uygulamalarını ve bu uygulamalardaki rant çabalarını ele alırken, 2019 yılında kent tarihi olarak adlandırılan kentsel değişimlerin kent yönetimi ve kentsel siyasetle ilişkili olduğuna dair araştırmalarda bulunulmuştur (Ek 1; Tablo 2).

Çalışmaların nasıl yapıldığına bakıldığında alan çalışması, literatür taraması ve proje incelemeleri olarak üç farklı yöntem karşımıza çıkmaktadır. Çalışmalar içerisinde en fazla literatür taramalarının ve tarihsel süreç içerisinde oluşturulmuş çeşitli kaynak incelemelerinin yapıldığ görülmektedir (Şekil 6).

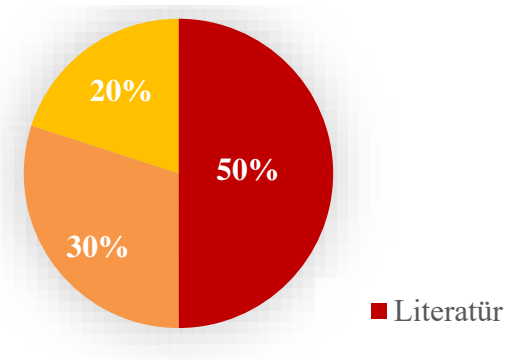

\section{Şekil 6. Çalışmaların Yöntem Dă̆ılımı}

Çalışmaların ele alınış şekillerine göre bakıldığında ekonomik devingenlik, mekânsal devingenlik ve toplumsal devingenlik/devingenlik kanalları olmak üzere üç farklı devingenlik grubuna ayrılmaktadır. Devingenlik çeşitlerine göre çalışmaların yapılma şekline bakıldığında her üç devingenlik türü için de literatür taramasından oluşan çalışmaların bulunduğu görülmektedir. Literatür taramasının haricinde diğer araştırma yöntemlerine bakıldığında ise; 'Mekansal Devingenlik' grubunda proje incelemesi; 'Toplumsal Devingenlik' grubunda ise hem alan araştırması hem de proje incelemesinin yapıldığı görülmektedir.

Alan araştırmasının yapıldığı üç çalışma spesifik olarak İstanbul Sümer Mahallesi, Adana ve Antakya üzerine yapılırken, Proje incelemesinin görüldüğü çalışmalarda Türkiye geneli yapılan projeler incelenmiş ve bunlar özelinde bulgular çıkartılmıştır. Literatür taramasında ise yine Türkiye geneli geçmişten günümüze konularla ilgili yapılan çalışmalar ve elde edilen kavramsal bulguların yer aldığı görülmüştür. Ayrıca göç temelinde yapılan incelemelerin çoğu literatür taraması ile tarihsel sürece bakarken, kentsel dönüşüm ve devingenlik konularını esas alan çalışmaların alan çalışması ya da proje incelemesi yöntemlerini kullandığı elde edilen bulgulardan biri olmuştur (Ek 1; Tablo 3). 
Tablo 3. Çalışmaların Hipotezleriyle İlişskilendirilen Kavramlar ve Yapılma Biçimlerinin Devingenlik Gruplarına Göre Dăğlımı

\begin{tabular}{|c|c|c|c|c|c|}
\hline \multirow{2}{*}{\multicolumn{3}{|c|}{ Devingenlik }} & \multicolumn{3}{|c|}{ Çalıșmaların Yapılma Șekli } \\
\hline & & & $\begin{array}{l}\text { Alan } \\
\text { Araştırması }\end{array}$ & $\begin{array}{l}\text { Literatür } \\
\text { Taraması } \\
\end{array}$ & $\begin{array}{l}\text { Proje } \\
\text { İncelemesi }\end{array}$ \\
\hline \multirow[t]{2}{*}{$\begin{array}{l}\text { Ekonomik } \\
\text { Devingenlik }\end{array}$} & $\begin{array}{l}\text { Hipotez } \\
\text { Kavramlart }\end{array}$ & Kentsel Dönüşüm - Katılım (MI) & & 1 & \\
\hline & & Toplam & & 1 & \\
\hline \multirow{3}{*}{$\begin{array}{l}\text { Mekansal } \\
\text { Devingenlik }\end{array}$} & \multirow{2}{*}{$\begin{array}{l}\text { Hipotez } \\
\text { Kavramlarl }\end{array}$} & Kentsel Dönüşüm - Rant (M2) & & & 1 \\
\hline & & Küreselleşme - Ayrışma (M5) & & 1 & \\
\hline & \multirow{8}{*}{$\begin{array}{l}\text { Hipotez } \\
\text { Kavramlart }\end{array}$} & 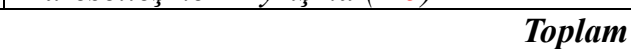 & & 1 & 1 \\
\hline \multirow{8}{*}{$\begin{array}{l}\text { Toplumsal } \\
\text { Devingenlik }\end{array}$} & & Kentsel Dönüşüm - Kent İ̧̧i Göç (M3) & 1 & & \\
\hline & & Kentsel Dönüşüm - Gecekondu (M4) & 1 & & \\
\hline & & Göç-Suç (M6) & & 1 & \\
\hline & & Yoksulluk - Yönetim (M7) & & & 1 \\
\hline & & Göç-Ayrışma (M8) & & 1 & \\
\hline & & Maddi Kültür - Devingenlik (M9) & 1 & & \\
\hline & & Kent Tarihi - Kentsel Siyaset (M10) & & 1 & \\
\hline & & Toplam & 3 & 3 & 1 \\
\hline
\end{tabular}

Çalışmaların hipotezlerinde ele aldıkları kavramların devingenlik gruplarına göre dağılımına bakıldığında, 'Kentsel Dönüşüm' her üç grupta yer alırken, mekânsal devingenlikte yer seçiminin bir yansıması olan 'Ayrışma' ve bu yer seçim hareketliliğini etkileyen 'Küreselleşme ve Rant' konuları incelenmektedir. Toplumsal devingenlikte ise, kitlesel geçiş süreçleri ve bu süreçlerin doğurduğu sonuçları içeren 'Göç, Gecekondu, Yoksulluk, Yönetim, Suç, Ayrışma, Devingenlik, Kültür ve Tarih' gibi kavramların ele alındığı görülmektedir (Tablo 3).

Tüm bunlarla beraber yıllardır süregelen göç hareketleri ile birlikte ortaya çıkan ve gerek ekonomik, gerek mekânsal, gerekse de toplumsal olan devingenlik olgusunun, günümüz kentlerinde sadece göç hareketleri ile değil aynı zamanda kent içerisinde yeni bir göç olgusunun oluşmasına neden olan kentsel dönüşüm uygulamalarıyla da etkileşim içerisinde olduğu Tablo 3'te de görülmektedir. Özellikle 2000'li yılların başından itibaren çıkartılan dönüşüm yasalarıyla birlikte gecekondu alanlarında uygulanan kentsel dönüşüm uygulamaları, bu hareketliliği tetiklemekte ve kent içerisinde belirli kanallar yoluyla yer seçmiş toplumların, yeniden şekillenmesine yol açmaktadır. $\mathrm{Bu}$ da yapılan çalışmaların ağırlıkla gecekondu alanlarındaki dönüşüm uygulamalarına yoğunlaşmasına neden olmaktadır (Ek 1; Tablo 3).

Tespit edilen yayınların neler olduğundan ziyade nasıl bir çalışma yürüttüğü ve bunun sonucunda ortaya koyduğu sonuç ve önerilerin neler olduğunun tespiti çalışmanın amacı için önemli olmaktadır. $\mathrm{Bu}$ yüzden analizler yapılırken sadece başlık ve hipotezler üzerinden değil çalışmaların sonucunda elde edien tespit ve bulgular üzerinden de incelemeler yapılmaya çalışılmıştır. Makalelerin elde ettiği toplam 57 bulgu incelenerek, hipotezlerle ilişkileri ortaya konmak istenmiştir. 'Göç'le ilgili yapılan araştırmalarda 'ayrışma, adalet, tarım, imar affı, ekonomik çatışma, enformel çalışma, toplumsal bütünleşme' gibi pek çok kavramla karşılaşılmaktadır. Bunun nedeni göçle ilgili yapılan çalışmalarda kente göç etme nedenleri, tarımda yetersizlik, göç ettikten sonra kentte görülen hem mekânsal hem de toplumsal sınıf farklılıkları ve bunun sonuçları konularına cevap aranması olmaktadır.

'Kentsel Dönüşüm' kavramını içeren yazılarda ise 'gecekondu, müdahale, yerel yönetim, merkezi yönetim, politika, e-ISSN: 2148-2683 ekonomik yapı, kimlik, müzakere, ayrışma, yerinde dönüşüm, rant' gibi pek çok kavramın ortaya çıktığı görülmektedir. Bunun nedeni ise, 2000'li yılların başlarından itibaren ortaya çıkan kentsel dönüşüm kavramıyla birlikte kentin çeşitli alanlarında, özellikle gecekondu alanlarında, uygulanan kentsel dönüşüm projeleri ve bu projelerin politika ve sonuçlarının tartışılması olmaktadir.

Dönüşüm uygulamalarında toplumsal yapının göz önünde bulundurularak müdahale kararları verilmesi ve bu süreçte müzakere yoluna başvurulması, kentsel dönüşüm çalışmalarında çözüm önerisi olarak görülmektedir. Ayrışma ya da bir başka deyişle dişlanma ise hem göç hem de kentsel dönüşüm çalışmalarında çözülmesi gereken bir sorun olarak karşımıza çıkmaktadır. Çalışmalara göre hem kent içerisindeki devingenliğin hem de farklı kentlerden göçle oluşan toplum gruplarının devingenliğinin hem nedeni hem de sonucu olan bu kavram çözümlenmediği takdirde, kentlerde sınıfsal farklılık ve bölünmelerin artacağı düşünülmektedir.

Pek çok kavram içerisinde dikkat çeken bir husus 'ekonomik yapının' göç, kentsel dönüşüm ve ayrışma konuları için çözüm oluşturabileceği düşünülmektedir. Göçerlerin gecekondu alanlarını tercih etmesinin yanında, kentsel dönüşüm uygulamaları sonucunda değişen alanda kalamamalarının nedeni olarak gösterilen ekonomik yap1, dönüşüm müdahalelerinde göz ardı edilemeyecek bir konu olarak karşımıza çıkmaktadır. Gecekondu alanlarındaki kişilerin ödeme güçleri dikkate alınarak uygulamaların yapılması, düşük gelir grubundaki kişilerin bulunduğu alanlardan başka alanlara gitmemelerine neden olacağı, bir nevi yerinde dönüşüme yol açacağı düşünülmektedir.

Bahsedilen iki kavramın dışında, küreselleşme ve yoksulluk konularının varlığı da görülmektedir. İncelenen konulardan biri olan küreselleşme, kendiyle birlikte ortaya çıkan rekabet ve gecekondu alanında yapılan kentsel dönüşüm ve tasfiyeleri tartışırken; bir diğeri yoksulluk ise eski 'işsizlik' tanımında uzaklaşıp biçim değiştirerek günümüzde kentsel dönüşüm, gecekondu, imar affı, yardım ve ötekileştirme konularıyla ele alınmaktadır. Göç ve kentsel dönüşümden çok uzak gibi görünse de aslında hem küreselleşme hem de yoksulluk, kentleşmedeki rolleriyle bahsettiğimiz tüm bu kavramlarla iç içe geçmiş durumdadir (Tablo 4). 
European Journal of Science and Technology

Tablo 4. Çalı̧̧malarda Elde Edilen Bulguların Konuları

\begin{tabular}{|c|c|c|c|c|c|}
\hline $\begin{array}{l}\text { Hipotezdeki } \\
\text { Temel } \\
\text { Kavramlar } \\
\end{array}$ & $\begin{array}{l}\text { Bulgulardaki Temel } \\
\text { Terimler }\end{array}$ & $\begin{array}{l}\text { Hipotezdeki } \\
\text { Temel Kavramlar }\end{array}$ & $\begin{array}{l}\text { Bulgulardaki Temel } \\
\text { Terimler }\end{array}$ & $\begin{array}{l}\text { Hipotezdeki } \\
\text { Temel } \\
\text { Kavramlar } \\
\end{array}$ & $\begin{array}{l}\text { Bulgulardaki Temel } \\
\text { Terimler }\end{array}$ \\
\hline \multirow{2}{*}{$\begin{array}{l}\text { Kentsel Dönüşüm } \\
\text { - Katıllm (M1) } \\
\end{array}$} & Kimlik & \multirow{5}{*}{$\begin{array}{l}\text { Küreselleşme - } \\
\text { Ayrışma (M5) }\end{array}$} & Ayrışma & \multirow{5}{*}{$\begin{array}{c}\text { Yoksulluk- } \\
\text { Yönetim (M7) }\end{array}$} & Yoksulluk \\
\hline & Müzakere & & Dişlanma & & Hayırseverlik \\
\hline \multirow{3}{*}{$\begin{array}{l}\text { Kentsel Dönü̈şüm } \\
\quad-\text { Rant (M2) }\end{array}$} & Ayrışma & & Kimlik & & Sosyal devlet \\
\hline & Sosyal yap 1 & & Tasfiye & & Ötekileştirme \\
\hline & Yerinde dönüşüm & & Rekabet & & Alt yoksulluk tanımları \\
\hline \multirow{9}{*}{$\begin{array}{l}\text { Kentsel Dönüşüm } \\
\text { - Kent İ̧i Göç } \\
\text { (M3) }\end{array}$} & Kültürel atıf & \multirow{18}{*}{ Göç-Suç (M6) } & Adalet & \multirow{2}{*}{$\begin{array}{c}\text { Göç - Ayrışma } \\
(\text { M8) }\end{array}$} & Ayrışma \\
\hline & Ekonomik çatışma & & Aktivite & & Enformel çalışma \\
\hline & Ödeme gücü & & Duyarsızlık & \multirow{8}{*}{$\begin{array}{l}\text { Maddi Kültür- } \\
\text { Devingenlik (M9) }\end{array}$} & Yapılara müdahale \\
\hline & Konut çeşitliliği & & Eğitim & & Modern tasarım \\
\hline & Yapılaşma çeşitliliği & & Göç & & Az işçilikli yapılar \\
\hline & Birlikte yaşama memnuniyeti & & İmar affi & & Ekonomik devingenlik sonucu \\
\hline & Halk katılımı & & & & mekansal devingenlik \\
\hline & Kısa süreçler & & \multirow{3}{*}{$\begin{array}{l}\text { Güvenlik altyapıs1 } \\
\text { Kentlilik bilinci }\end{array}$} & & Sit alanı \\
\hline & İhtiyaçlarına göre dönüşüm & & & & Suriye göçü \\
\hline \multirow{9}{*}{$\begin{array}{l}\text { Kentsel Dönüşüm } \\
\text { - Gecekondu } \\
\text { (M4) }\end{array}$} & & & & & Restorasyon \\
\hline & $\begin{array}{l}\text { fecekonau kavramındi uç } \\
\text { farkem }\end{array}$ & & Toprak dağılımı & \multirow{8}{*}{$\begin{array}{l}\text { Kent Tarihi- } \\
\text { Kentsel Siyaset } \\
\quad(\text { M10) }\end{array}$} & $\begin{array}{l}\text { Soylulaştırma ve mekansal } \\
\text { eşitsizlik }\end{array}$ \\
\hline & & & & & Kentsel toplumsal hareketler \\
\hline & $\begin{array}{l}\text { Dönüşüm ile kente doğrudan } \\
\text { müdahale (TOKİ, Merkezi }\end{array}$ & & Plan sürecine güvenlik & & $\begin{array}{l}\text { 1980-2000 aras1 kentsel } \\
\text { siyaset }\end{array}$ \\
\hline & yönetim ve Müteahhit eliyle) & & & & \\
\hline & \multirow{4}{*}{$\begin{array}{l}2000 \text { sonrası kentsel dönüşüm } \\
\text { kavramı }\end{array}$} & & \multirow[t]{2}{*}{ Sivil Toplum Kuruluşları } & & \\
\hline & & & & & Kentsel dönüşüm \\
\hline & & & Tarım desteği & & $\begin{array}{l}\text { Gecekondu alanlarındaki } \\
\text { değişimler }\end{array}$ \\
\hline & & & Yoksulluk & & Merkezi yönetim \\
\hline
\end{tabular}

Bir nevi Tablo 4'ün sağlaması olacağı düşüncesiyle 'çalışmalarda hangi kelimelerin öne çıktığı' sorusuna yanıt aranmış ve bu soru doğrultusunda 'Wordcounter (2021)' adlı internet sitesi üzerinden çalışmaların tam metinlerinin kelime bulutu taranarak hangi kelimelerin ağırlıkla kullanıldığı ortaya konmuştur ( $\mathrm{Bu}$ tarama yapılırken 've, ile, gibi v.b. bağlaçlar taramanın dışında tutulmuştur). Tablo 5'te her bir çalışmanın kendi içerisinde $\% 2$ ve üzeri çıkan kelimeler verilmiştir. Çalışmaların bulgularının içerdikleri konular (Tablo 4) ile çalışmalarda en fazla kullanılan kelimeler (Tablo 5) birlikte incelendiğinde bulgular ile en fazla kullanılan kelimelerin birbirini tamamladığ 1 , çalışmada anlatılan devingenlik kavramı ile göç ve kentsel dönüşümün bu kavram ilişkisini açıklayan konuların araştırmalarda sıklıkla kullanıldığı görülmektedir.

Tablo 4 ve 5 birlikte incelendiğinde 'kentsel' kavramlarının her çalışmada yer aldığı; bununla birlikte çalışmaların birçoğunda 'göç' sonucu ortaya çıkan 'gecekondu' alanlarının konu olarak ele alındığı görülmektedir. İncelenen on çalışma amaç ve yöntem bakımından birbirinden ne kadar farklı olursa olsun, içerik olarak incelendiğinde göçle oluşan gecekondu alanları ve alanlarda yer alan toplumsal gruplar (yoksulluk, suç, ayrışma, kimlik v.b.) ve de 2000'li yıllardan sonra çıkartılan dönüşüm yasalarıyla birlikte bahsedilen bu gecekondu alanlarına uygulanan müdahale ve yaklaşımların (tasfiye, yönetim, siyaset, rant, ekonomik devingenlik, mekânsal devingenlik, ekonomik çatışma, ötekileştirme v.b.) kente hem toplumsal, hem mekânsal hem de ekonomik yansımaları etrafında geçtiği görülmektedir.
Tablo 5. Çalışmaların Kelime Bulutunda En Fazla Yer Alan Kelimeler

\begin{tabular}{|c|c|c|c|c|c|}
\hline $\begin{array}{l}\text { Makale } \\
\text { kodu }\end{array}$ & Kelime & $\begin{array}{l}\text { Yüzde } \\
(\%)\end{array}$ & $\begin{array}{c}\text { Makale } \\
\text { kodu }\end{array}$ & Kelime & $\begin{array}{l}\text { Yüzde } \\
(\%)\end{array}$ \\
\hline \multirow{4}{*}{$M 1$} & Kentsel & 8 & \multirow{7}{*}{ M5 } & Kentsel & 3 \\
\hline & Gecekondu & 5 & & Mekansal & 2 \\
\hline & Dönüşüm & 3 & & Küresel & 2 \\
\hline & Kent & 2 & & Toplumsal & 2 \\
\hline \multirow{7}{*}{$M 2$} & Kent & 4 & & Yeni & 2 \\
\hline & Kentsel & 3 & & Üretim & 2 \\
\hline & Sosyal & 2 & & Ekonomik & 2 \\
\hline & Yeni & 2 & \multirow{5}{*}{ M6 } & Göç & 5 \\
\hline & Yoksulluk & 2 & & Kent & 2 \\
\hline & \multirow{2}{*}{ Gecekondu } & \multirow{2}{*}{2} & & Suç & 2 \\
\hline & & & & Kentleşme & 2 \\
\hline \multirow{7}{*}{$M 3$} & Göç & 8 & & Kırsal & 2 \\
\hline & Kentsel & 4 & \multirow{5}{*}{$M 7$} & Sosyal & 8 \\
\hline & Dönüşüm & 3 & & Yardım & 6 \\
\hline & Hane & 3 & & Yoksulluk & 6 \\
\hline & Yapilan & 2 & & Yeni & 2 \\
\hline & & & & Gelir & 2 \\
\hline & Başkalarının & 2 & \multirow{3}{*}{$M 8$} & Göç & 6 \\
\hline \multirow{10}{*}{ M4 } & Gecekondu & 5 & & Toplumsal & 3 \\
\hline & Konut & 4 & & Mekansal & 2 \\
\hline & Kentsel & 3 & \multirow{5}{*}{ M9 } & Antakya & 6 \\
\hline & Yerel & 2 & & Ev & 3 \\
\hline & Yeni & 2 & & Eski & 3 \\
\hline & Belediye & 2 & & Yer & 2 \\
\hline & Yerel & 2 & & Kent & 2 \\
\hline & Adana & 2 & \multirow{3}{*}{$M 10$} & Kentsel & 8 \\
\hline & Dönüşüm & 2 & & Siyaset & 3 \\
\hline & İmar & 2 & & Yerel & 3 \\
\hline
\end{tabular}




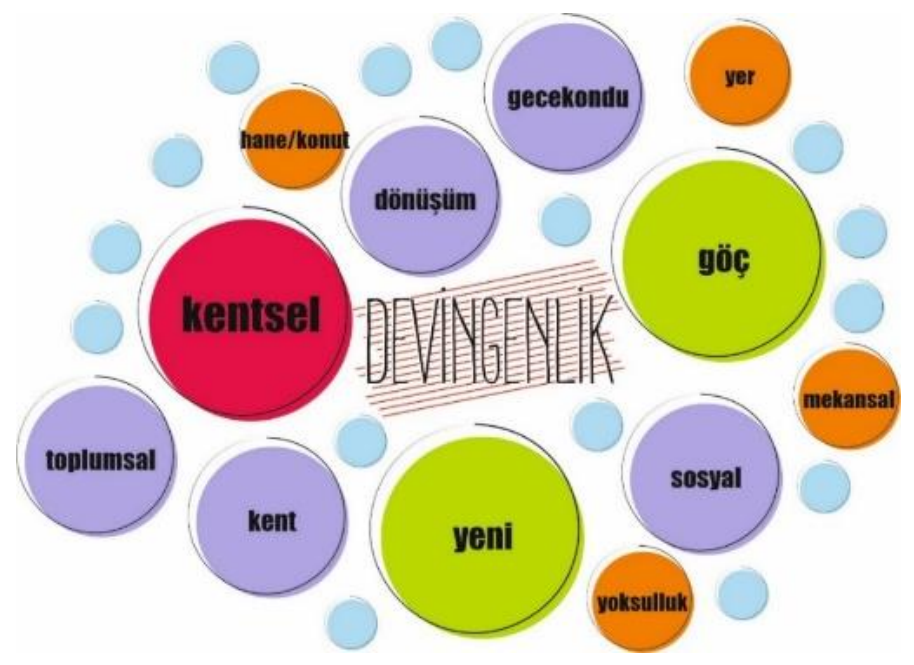

Şekil 7. Araştırmalarda Ortak Kullanılan Kavramların Kullanım Yoğunluğunun Şematik Gösterimi

Kelime bulutu incelenirken makalelerde ortak kullanılan kelimeler tespit edilmiştir (Şekil 7). Seçilen on makalede ortak olarak kullanılan kelimelere bakıldığında en üst sırada 'kentsel' kelimesi bulunmaktadır ki bu da devingenliğin konu edinildiği bu çalışmaların kente dair ortaya çıkan çeşitli sorun ya da konular üzerinden üretildiğini göstermektedir. İkinci sırada yer alan 'göç' devingenliğin göç süreçleri üzerine olmasını ifade etmekle birlikte 'yeni' kelimesi üçüncü sırada yer alan dönüşümleri de içine alacak şekilde değişken bir durumu ifade etmektedir olarak yorumlanabilir. Ortak kullanılan ve her bir makalede en çok öne çıkan diğer kelimeler ise 'gecekondu, toplumsal, kent, sosyal, hane/konut, yer ve mekânsal' olmuştur.

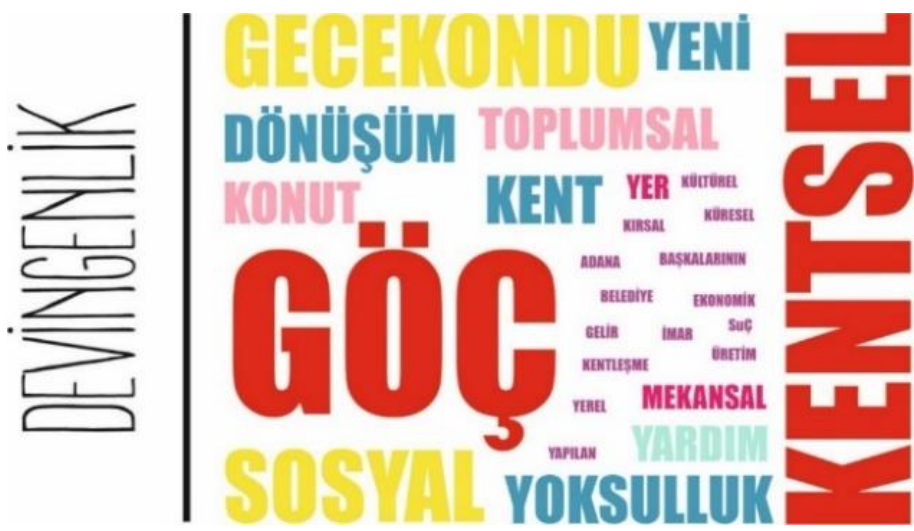

Şekil 8. Çalışmalara Bütün Olarak Bakıldı̆̆ında Kullanılan Kelimelerin Yer Alma Ağırlıklarının Şematik Gösterimi

Devingenliği içeren on makalede öne çıkan kelimelerin kullanılma sayısı toplamına göre değerlendirildiğinde birinci sırayı 'göç', ikinci sırayı 'kentsel', üçüncü sırayı ise 'gecekondu' ve 'sosyal' kelimeleri almaktadır. Şekil 8, bizlere bu kelimelerin toplam on çalışmada ne kadar sıklıkla kullanıldığını göstermektedir. Buna bağlı olarak devingenlik kavramının doğrudan ele alınmaması ile birlikte 2000 sonrası çalışmalarda da kentsel alanlarda göç ve gecekondu süreçleriyle birlikte değerlendirildiğini göstermektedir. Bununla birlikte ekonomiye yönelik kavramların daha az tartışılır olması ise kentsel dönüşüm uygulamalarının artması ve devingenliğin de ağırlıkla mekânsal olarak ele alındığını ifade etmektedir. Şekil 7 ve Şekil 8'e bakıldığı zaman ikisinde de 'göç, kentsel, toplum, gecekondu, dönüşüm, sosyal' gibi kelimelerin öne çıktığı ve bu kelimelerin aslında göçle ortaya çıkmış kentleşmenin, kentsel dönüşüm uygulamalarının ve toplum gruplarının her bir çalışma için önemli konular olduğunu gözler önüne sermektedir. Ancak tüm bu konular ele alınırken, çeşitli kentleşme kuramlarının da yaklaşımlarında olduğu gibi bu kavramların temelini oluşturan ve şekillendiren devingenlik ve devingenlik kanallarına çok fazla yer verilmemektedir.

Tüm bu bulgular 1şığında bakıldığında elde edilen verilerin bir özeti olarak Tablo 6'daki gibi bir durum karşımıza çıkmaktadır. Buna göre en çok karşımıza çıkan kavramlar 'ayrışma/dışlanma" ve "toplumsal yapı" olmaktadır. Bulgular içerisinde en çok kullanılan kavramlardan biri olan "ayrışma", kentleşme ve kentleşme sürecini tanımlamaya çalışan kuramsal yaklaşımların ortaya koyduğu bir kavram olmakta ve kentin olmazsa olmaz bir yapı taşı olarak görülmektedir. Özellikle mekânsal ve toplumsal devingenlik konularıyla ilişkisi kurulan bu kavram, kent ve kentleşme sürecinin şekillendiricisi olan toplumsal grupların gerek kendiliğinden yaptıkları göç hareketleri, gerekse de kentsel dönüşümün de içerisinde bulunduğu müdahalelerin tetiklemesi sonucunda birbiri içerisindeki geçişlerinin ortaya çıkardığı bir durum olarak karşımıza çıkmaktadır. Bu yüzdendir ki bir diğer kavram olarak "toplumsal yapı" çeşitli bulgular içerisinde en fazla kullanılan diğer bir olgu olmaktadır. Bahsedilen bu iki unsur birbiri ile ilişki olarak gerek kentleşme müdahaleleri gerekse de göç hareketleri ile doğrudan ilişkili olmaktadır.

Tabloya göre öne çıkan 'ekonomik yapı', 'kimlik' ve 'yoksulluk' konuları incelendiğinde ise; toplum gruplarının kente geldikten sonra kente tutunma ve kentle bütünleşme çabalarının sonucunda önemli bir hal alan 'kimlik' hem ekonomik nedenli devingenlik, hem mekânsal devingenlik hem de toplumsal devingenliğin üçünde de bir sonuç ya da çözüm olarak ortaya çıkmaktadır. Kimliğin yanı sıra kente entegre olma çabaları içerisindeki bir diğer unsur olan ekonomik koşullar ve bunun sonucunda ortaya çıkan yoksulluk durumu ise göçle gelen kişilerin kentlerde kurduğu ilişkilerin şekillendirdiği bir durum olmaktadır. Devingenlik ve devingenlik kanallarının yol açtığı toplumsal biçimlenmelerin süreç içerisindeki değişimi incelendiğinde günümüzde hemşerilik ilişkilerinin yanı sıra iş ilişkilerinin de oluşturduğu devingenlik biçimlerinin önemi bu çalışmalarda da göze çarpmaktadır.

Ayrıca, toplumsal devingenlikle birlikte ele alınan çalışmalarda 'kentsel dönüşüm, ayrışma, birlikte yaşam, imar affı, ödeme gücü, göç, kentlilik ve bütünleşme, ötekileştirme ve yoksulluk' kavramları, bulgular ve çözüm önerileri olarak karışımıza çıkmaktadır. Ekonomik devingenlikte 'kimlik ve müzakere' görülürken, mekânsal devingenlikte de 'ayrışma, dışlanma, kimlik, rekabet, tasfiye, yerinde dönüşüm' kavramlarının öne çıktığı görülmektedir. Elde edilen bulguların benzerliği ve çakışmasından da anlaşılacağı üzere devingenlik kavramları çeşitlilik gösterse de her biri birbiri ile ilişkili ve etkileşim halinde olmakla birlikte, bu üç devingenlik türünün de 'göç' ve göçle oluşmuş gecekondu alanlarında uygulanan 'kentsel dönüşüm’ müdahaleleriyle birlikte ele alınması gerekmektedir. 
European Journal of Science and Technology

Tablo 6. Bulguların Devingenlik Gruplarının Ortaya Koymaya Çalıştı̆̆g Hipotezlere Göre Dağıllımı

\begin{tabular}{|c|c|c|c|c|c|c|c|c|c|c|c|}
\hline \multirow{3}{*}{ Bulgular } & \multicolumn{11}{|c|}{ Devingenlik Türlerine Göre Çalışmaların Hipotezleri } \\
\hline & \multirow{2}{*}{\begin{tabular}{|c|}
$\begin{array}{c}\text { Ekonomik } \\
\text { Devingenlik }\end{array}$ \\
$\begin{array}{c}\text { Kentsel } \\
\text { Dönüşüm- } \\
\text { Katllım }\end{array}$ \\
\end{tabular}} & \multicolumn{2}{|c|}{ Mekansal Devingenlik } & \multicolumn{7}{|c|}{ Toplumsal Devingenlik } & \multirow{2}{*}{ Toplam } \\
\hline & & $\begin{array}{c}\text { Kentsel } \\
\text { Dönüsüum- } \\
\text { Rant }\end{array}$ & $\begin{array}{l}\text { Küreselleşme } \\
\text {-Ayrı̧̧̧a }\end{array}$ & $\begin{array}{c}\text { Kentsel } \\
\text { Döüsüum- } \\
\text { Kentiçi Gọ̧̈ }\end{array}$ & $\begin{array}{c}\text { Kentsel } \\
\text { Döüsüum- } \\
\text { Gecekondu }\end{array}$ & Gọ̈-Suç & $\begin{array}{l}\text { Yoksulluk } \\
\text {-Yönetim }\end{array}$ & $\begin{array}{c}\text { Gọ̈̈- } \\
\text { Ayrı̧̧ma }\end{array}$ & $\begin{array}{c}\text { Maddi } \\
\text { Kültuir- } \\
\text { Devingenlik }\end{array}$ & $\begin{array}{c}\text { Kent } \\
\text { Tarihi- } \\
\text { Kentsel } \\
\text { Siyaset }\end{array}$ & \\
\hline Ayrışma / Dışlanma & & 1 & 2 & & & & 1 & 1 & & & 5 \\
\hline Toplumsal Yapı & & 1 & & 4 & & & & & & & 5 \\
\hline Ekonomik Yapr & & & & 2 & & & & 1 & & & 3 \\
\hline Kimlik & 1 & & 1 & 1 & & & & & & & 3 \\
\hline Yoksulluk & & & & & & 1 & 2 & & & & 3 \\
\hline $\begin{array}{c}\text { Güvenlik } \\
\text { Kurumu/Altyapıst } \\
\end{array}$ & & & & & & 2 & & & & & 2 \\
\hline Müzakere & 1 & & & 1 & & & & & & & 2 \\
\hline Tarıma Yönlendirme & & & & & & 2 & & & & & 2 \\
\hline Toplum Bilinci & & & & & & 2 & & & & & 2 \\
\hline Gecekondu & & & & & 1 & & & & & 1 & 2 \\
\hline $\begin{array}{l}\text { Kente ya da Yapllara } \\
\text { Müdahale }\end{array}$ & & & & & 1 & & & & 1 & & 2 \\
\hline Kentsel Dönüsü̈m & & & & & 1 & & & & & 1 & 2 \\
\hline Adalet & & & & & & 1 & & & & & 1 \\
\hline Aktivite & & & & & & 1 & & & & & 1 \\
\hline Duyarsızlık & & & & & & 1 & & & & & 1 \\
\hline Gö̧ & & & & & & 1 & & & & & 1 \\
\hline Haylrseverlik & & & & & & & 1 & & & & 1 \\
\hline Imar Affi & & & & & & 1 & & & & & 1 \\
\hline Modern Tasarm & & & & & & & & & 1 & & 1 \\
\hline Az İşilikli Yaplar & & & & & & & & & 1 & & 1 \\
\hline $\begin{array}{l}\text { Ekonomik devingenlik } \\
\text { sonucu mekansal } \\
\text { devingenlik }\end{array}$ & & & & & & & & & 1 & & 1 \\
\hline Sit Alanı & & & & & & & & & 1 & & 1 \\
\hline Suriye Göçü & & & & & & & & & 1 & & \\
\hline Restorasyon & & & & & & & & & 1 & & 1 \\
\hline Rekabet & & & 1 & & & & & & & & 1 \\
\hline $\begin{array}{l}\text { Soylulassttrma ve } \\
\text { Mekansal Eşitsizlik }\end{array}$ & & & & & & & & & & 1 & 1 \\
\hline $\begin{array}{l}\text { Kentsel Toplumsal } \\
\text { Hareketler }\end{array}$ & & & & & & & & & & 1 & 1 \\
\hline $\begin{array}{c}\text { 1980-2000 Arast } \\
\text { Kentsel Siyaset }\end{array}$ & & & & & & & & & & 1 & 1 \\
\hline $\begin{array}{l}2000 \text { Sonrast Kentsel } \\
\text { Politikalardaki Köklü } \\
\text { Değisisimler }\end{array}$ & & & & & & & & & & 1 & 1 \\
\hline $\begin{array}{c}\text { Sivil Toplum } \\
\text { Kurulussları } \\
\end{array}$ & & & & & & 1 & & & & & 1 \\
\hline Sosyal Devlet & & & & & & & 1 & & & & 1 \\
\hline Süreç & & & & 1 & & & & & & & 1 \\
\hline Tasfiye & & & 1 & & & & & & & & 1 \\
\hline Yerel Yönetim & & & & & 1 & & & & & & 1 \\
\hline Merkezi Yönetim & & & & & & & & & & 1 & 1 \\
\hline Yerinde Dönüşüm & & 1 & & & & & & & & & 1 \\
\hline Toplam & 2 & 3 & 5 & 9 & 4 & 13 & 5 & 2 & 7 & 7 & 57 \\
\hline
\end{tabular}

\section{Değerlendirme ve Sonuç}

Devingenlik özü itibariyle hareketli ve sürekli bir eylemi ifade etmektedir. $\mathrm{Bu}$ anlamda göç, göç sonucu yapılaşma, kentlerde göçle oluşan yaşam alanları, ekonomik düzen ve daha birçok konuyla paralel ilerlemekte; bu kavramları devingenlik kavramından bağımsız düşünmeyi olanaksız kılmaktadır. Türkiye kentleşme pratiğinin kır-kent ikileminde gelișen göç temelli sınıflı toplum yapısı, şartlarını iyileştirme çabası içerisindeki gruplar açısından devingenliği farklı açılardan zorunlu kılmıştır. Bu bağlamda toplumsal ilişkileri kullanarak ya da kentsel arsa ve konut piyasasının yarattığı olanakları geliştirerek elde edilen yeni konumlar kentleşmenin temel dinamiğini oluşturmuştur. $\mathrm{Bu}$ 
bağlamda 2000'ler sonrasının konum ve yer edilme süreçlerini bütünüyle yeniden tarif eden bir içerikle yapılandığı açıktır. Büyük ölçekli kentsel müdahaleler dönemi olarak anılan bu süreçte, ağırlıkla kendisine göçle oluşmuş yaşama alanlarını hedef seçen projeler, geniş toplulukların yaşam şartlarında ani ve dönüştürücü etkiler açığa çıkarırken, esasen devingenlik açısından da yeni koşullar tanımlamaktadır. $\mathrm{Bu}$ noktadan hareketle çalışmada devingenliğin 2000 sonrası süreçte nasıl ele alındığı yapılmış araştırmalar üzerinden ortaya konmaya çalışılmıştır. İncelenen çalışmalarda doğrudan 'devingenlik' kavramına yönelik yeterli inceleme ve çıkarımların yapılmadığ 1 görülmekle birlikte; göç, kentte yer seçme ve bu yer seçim sonrası ortaya çıkan gecekondu, kente entegrasyon gibi pek çok durum ve konu ve de son olarak planlamanın bir müdahale biçimi olarak karşımıza çıkan kentsel dönüşüm uygulamaları ve bu uygulamaların etkileri olmak üzere oldukça geniş bir skalaya yayılan bir çalışma zinciri olduğu göze çarpmaktadır. Bu skala içerisinde göç denilince akla gelen ilk şey toplumsal yap1, kimlik, imar ve yapılaşma, toplumsal ayrışma ya da bütünleşme olurken, kentsel dönüşümde müzakere / katılım, gecekondu, tasfiye, ekonomik yapı, yerinde dönüşüm olmaktadır. Başta da ele aldığımız şekliyle kent içi yer değiştirmenin bir tetikleyicisi olarak görülen kentsel dönüşüm kavramının hem ekonomik, hem mekânsal, hem de toplumsal devingenlik gruplarında bulunuyor olması, kentsel dönüşümün sadece mekânsal bir uygulama olmayıp aynı zamanda ekonomik ve toplumsal olarak da değişikliklere yol açtığ 1 düşüncesini ortaya çıkartmaktadır. Bu noktada kentsel dönüşüm uygulaması günümüz kentlerinde toplum gruplarının hareketliliği için tetikleyici bir unsur olarak karşımıza çıkmakta ve göç hareketleri gibi kentlerde bulunan ekonomik, toplumsal ve mekânsal durumların her biriyle doğrudan ilişkili olup, devingenlik yaratmaktadır. Bahsedilen konular göz önünde bulundurulduğunda, sadece mekânsal müdahaleler yerine alanda yaşayanların sosyo-kültürel ve ekonomik durumunu da dikkate alan uygulamalarla kentlerde ortaya çıkan ekonomik, toplumsal ve mekânsal devingenliklerin biçimlenmeleri farklılaştırılabilmektedir.

Çalışmanın başlarında da bahsedildiği gibi kent ve kentleşme sürecini açıklamaya çalışan Chicago Okulu yaklaşımları, Harvey ve Castells gibi kuramcılar, "ayrışma-farklılaşma” kavramlarının kentin olmazsa olmazı olduğunu söyleyerek, kent sisteminin bunun üzerine kurulu olduğunu savunmaktadır. Bahsedilen bu ayrışma sadece mekânsal olmayıp, aynı zamanda toplumsal ve ekonomik katmanları da içerisinde barındırmaktadır. Göç süreciyle birlikte başlayan kentleşme tartışmaları, kente gelen göçerlerin kentlerde yer seçimi ile başlayan ve kente tutunma çabaları ve entegrasyonu ile devam eden bir dönemin günümüze kadar gelmektedir. Tüm bu süreci şekillendiren devingenlik olgusu, başlarda akrabalık ve hemşerilik kanallarıyla görülürken, zaman içerisinde ekonomik ilişkilerin ve iş imkanlarının belirleyici olduğu kanallarla şekillenmektedir. Kentleri ve toplumları şekillendiren devingenlik, göçle başlayan ve günümüzde kentsel dönüşümün yol açtığı hareketliliklerde devam eden bir olgu iken, bu iki kavramla ilişkili olarak çalışmalarda da ortaya çıkan 'ötekileşme, ayrışma, dışlanma, yoksulluk, kentleşme, kentlileşme, toplum grupları, entegrasyon, kent içi yer değiştirmeler v.b.' konularının her birini şekillendirmektedir. Bu yüzdendir ki devingenlik araştırılması ve ortaya konulması gereken önemli bir belirleyici olarak karşımıza çıkmaktadır.

Sonuç itibariyle görülen çalışmalarda devingenlik yer almasına rağmen doğrudan kavrama ilişkin çalışmaların yapılmamış olması ile birlikte göç, gecekondu ve devingenliği doğrudan tanımlayan 2000 öncesi yazarların kullanımlarını doğrudan metin içerisinde geçirerek ele alındığıdır. Çalışmalar içerisinde yer verilen kelimelerin sayıca yoğunluğuna bakıldığında 'kentsel, göç, gecekondu, dönüşüm, toplumsal v.b.' kavramlar sıklıkla tercih edilmektedir. Bu da kavramsal çerçevede yapılan çalışmalar ve açıklamalarla birebir örtüşen bir nokta olan devingenlikle birlikte bahsi geçen diğer kavramların birbirini etkilediği düşüncesini güçlendirmektedir. Bununla birlikte 73 . Madde ve 6306 sayılı kanun kapsamında uygulanan kentsel dönüşüm müdahalelerinin yoğun olduğu yılları takiben, çalışmalarda kentsel dönüşüm-devingenlik ve göç konularının ele alınması, bahsedilen etkileşimin bir başka göstergesi olmaktadır. Yapılan tüm bu çalışma sonucunda göç, kentsel dönüşüm ve devingenlik kavramlarının birbiriyle ilişkili ve karşılıklı etkileşim içerisinde olduğu görülmektedir.

2000 öncesi göç hareketleri ve yol açtığı devingenlik durumu, 2000 yılı sonrası ise kentsel dönüşüm uygulamaları ve bu uygulamaların yol açtığı kent içi göç hareketleri ilişkisine 1 şı tutan çalışmalar bulunurken; göçle oluşmuş gecekondu alanlarında görülen kentsel dönüşüm uygulamalarının kentlerde ve toplum gruplarında ortaya çıkarttığı ekonomik, toplumsal ve mekânsal devingenlikleri üzerine incelemelerde bulunulmadığı, bunların ilişkisinin sadece kavramsal çerçevede kısaca bahsedildiği göze çarpmaktadır. Oysa kent ve kentleşme süreci, toplumsal grupların şekillendirdiği dinamik bir yapıdadır ve bu dinamik yapıyı anlamak için sadece kentlere yapılan göç hareketleri ile bu hareketlerin sonucu olarak ortaya çıkan gecekondu alanlarına uygulanan ve günümüzde kentlerde yeni bir göç kavramının ortaya çıkmasına neden olan kentsel dönüşüm müdahalelerinin incelenmesi yeterli olmayacaktır. Toplum grupları ve onların yapmış olduğu devingenlik türleri ile ilişkili olan kentleşme sürecini açıklayabilmek için toplumun devingenlik kanalları ve bu kanalların yol açtığı biçimlendirmelerin iyi analiz edilmesi gerekmektedir.

Daha çok kavramsal olarak bir süreç tanımlamak için ele alınan devingenlik kavramı, çalışmada teorik olarak ele alınan yaklaşımlarla benzerlik gösterse de yapılan bu çalışma sonucunda kentlerin ve toplum gruplarının şekillenmesini sağlayan en temel unsurlardan biri olan devingenlik olgusuyla ilgili derinlemesine incelemelerin eksik kaldığı ve bahsedilen kavrama ilişkin derinlemesine çalışmaların yapılarak literatürde bulunan bu boşluğun doldurulması gerektiği görüşü ortaya çıkmaktadır.Bu noktada kentsel mekanlarda bulunan toplumsal grupların devingenlik tercihleriyle ilgili derinlemesine çalışmalar yapılması önemli hale gelmektedir.

\section{Kaynakça}

Ağın, C., Tezcan, S., \& Zengin Çelik, H. (2018). Göç, gecekondu ve kentsel dönüşüm konularında yapılan tezler üzerinden teorik çerçevenin değişiminin izlenmesi. II: Uluslararası Multidisipliner Akademik Çalışmalar Sempozyumu Tam Metin Bildiriler Kitabl (s. 663-675). İstanbul: Berikan Yayınevi.

Castells, M. (2017). Kent, sinıf, iktidar (2. Baskl). Ankara: Phoenix Yayınevi.

Çetin, İ. (2010). Gecekondunun kentle bütünleşme sürecinde alan-mekân faktörü: İzmir örneği. Doktora tezi, Ege Üniversitesi, İzmir.

Davis, M. (2010). Gecekondu gezegeni (2. Baskl). İstanbul: Metis Yayınc1lik. 
Epli İşler, N. (2010). İstanbul'un 1950 sonrası göç ile değişen kent ve mimari dokusunun sinemadaki temsili. Yüksek lisans tezi, İstanbul Teknik Üniversitesi, İstanbul.

Erder, S. (2001). $\ddot{U}_{c}$ Tip Hanenin Özel Analizi. https://www.capital.com.tr/ekonomi/makro-ekonomi/uc-tiphanenin-ozel-analizi

Erder, S. (2013). İstanbul'a bir kent kondu: Ümraniye. İstanbul: İletişim Yayınları.

Erdoğan, M. M. (2020, Şubat 17 - 21). 3. Göç Sertifika Programı. Göçe genel bakış ve Türkiye'deki sosyal uyumluluk çerçevesi sunumu. İzmir: Konrad Adenauer Stiftung, Türk-Alman Üniversitesi Göç ve Uyum Araştırmaları Merkezi ve Yaşar Üniversitesi UNESCO Uluslararası Göç Kürsüsü İşbirliği ile Düzenlenen Sınırlı Katılımcılı Eğitim Programı.

Ersoy, M. (1994). Kente göç eden nüfusun konut sorunu. Konut 94 içinde (ss. 59-66). Ankara: Batıkent Konut Üretim Yap1 Koop Yayını.

Geniş, Ş. \& Köse Akkirman, D. (2020). Eşitsizlik mekanları olarak mahalleler ve kadınların kent hakk1. Amme Idaresi Dergisi, 53(1), 1-35.

Googlescholar. (2021). “DEVİNGENLİK” AND “GÖÇ” AND "KENTSEL DÖNÜŞÜM", kalıbı ile tarama yapılan arama motoru. www.googlescholar.com. Ekim 2021.

Güreşçi, E. (2010). Köyden kente göçün köydeki ve kentteki yansımaları: Akpınar köyü üzerine bir değerlendirme. Sosyal ve Beşeri bilimler Dergisi, 47-55.

Hanushek, E.A. ve Quigley, J.M. (1978). An explicit model of intra-metropolitan mobility. Land Economics, 54 (4), 411429.

Harvey, D. (2002). Sınıfsal yapı ve mekânsal farklılaşma kuramı. 20. Yüzyıl Kenti (1. Baskı) (s. 147-172). içinde Ankara: İmge yayınevi.

Harvey, D. (2015). Asi şehirler (1. Baskl). İstanbul: Metis Yayıncilık.

Işık, O., \& Pınarcıoğlu, M. M. (2011). Nöbetleşe yoksulluk: Sultanbeyli örneği (11. Baskl). İstanbul: İletişim Yayıncılık.

İçduygu, A., \& Sirkeci, İ. (1999). Cumhuriyet Dönemi Türkiye'sinde Göç Hareketleri. M. Celal içinde, 75 Yılda Köylerden Şehirlere (s. 249-268). İstanbul: Tarih Vakfı Yayınları.

Kadıŏlu Ateş, H. ve Adam, E. (2016). “Kitap Özeti: Gecekondu Araştırması". Çekmece IZÜ Sosyal Bilimler Dergisi, 4 (8-9), 349-373.

Keleş, R. (2015). 100 soruda Türkiye'de kentleşme, konut ve gecekondu (2. Baskl). İstanbul: Cem Yayınevi.

Keskin, E. (2017). Kafamda Bir Tuhaflık ve İstanbul'a Göç Üzerine Notlar. https://medium.com/@eliflik/kafamda-birtuhaflik-ve-istanbula-göç-üzerine-notlar-f8928161df44

Kızılay, Ş. E. (2016). “Kentsel Alanda Gecekondu'dan Kentsel Dönüşüm'e Mekânsal Süreçler: Yaklaşımlar ve Tespitler”. OPUS Uluslararası Toplum Araştırmaları Dergisi, 6 (11), 717-761.

Koç, A. (2012). Sosyoloji Literatüründe ve Sinemada Gecekondudan Varoşa Değişen Söylem Biçimleri. İstanbul: T.C. İstanbul Üniversitesi.

Koyuncu, A. (2015). Kentleşme ve göç (1. Baskl). İstanbul: Hikmetevi Yayınları.

Lefebre, H. (2017). Şehir hakkl (2. Baskl). İstanbul: Sel Yayıncilik.

Özden, P. P. (2016). Kentsel Yenileme. Ankara: İmge Kitabevi.

Özgür, E. M., \& Yasak, Ü. (2009). "Şehir İçi İkametgah Hareketliliğine Kuramsal Bir Bakış”. Coğrafi Bilimler Dergisi, 39-50.
Serter, G. (2013). Şikago okulu kent kuramı: Kentsel ekolojik kuram. Planlama Dergisi, 67-76.

Şenyapıl1, Ö. (1981). Kentleşemeyen Ülke, Kentlileşen Köylüler. Ankara: ODTÜ Mimarlık Fakültesi Ara- Yayınları.

Şenyapılı, T. (1977). Integration Through Mobility. M.B.T.V. Journal of the Faculty of Architecture, 3 (2), 237-252.

Şenyapıl1, T. (1978). Bütünleşmemiş kentli nüfus sorunu. Ankara: Orta Doğu Teknik Üniversitesi Yayınları.

Şenyapılı, T. (1981). Gecekondu 'Çevre' İşçilerin Mekânı. Ankara: ODTÜ Mimarlık Fakültesi Yayını.

TDK (2020). Türk Dil Kurumu Güncel Sözlük: https://sozluk.gov.tr/

Tezcan, S. (2020a). Göçle Oluşmuş Yaşama Bölgelerine Yönelik Dönüşüm Projelerinde Müzakereler (Doktora Tezi). İzmir.

Tezcan, S. (2020b). Türkiye'de Göçle Oluşmuş Yaşama Bölgelerine Yönelik Yasal Müdahaleler ve Kentsel Dönüşüm Uygulamaları. Planlama Dergisi, 30 (3), 361-373.

Tezcan, S., \& Zengin Çelik, H. (2017). İzmir Büyükşehir Belediyesi Tarafından Uygulanan Kentsel Dönüşüm Projeleri Üzerine Bir İnceleme. Büyükçekmece I. Uluslararası Yerel Yönetimler Kongresi. İstanbul.

Tekeli, İ. (2015). Kent, kentli haklarl, kentleşme ve kentsel dönüşüm (2. Baskl). İstanbul: Tarih Vakfı Yurt Yayınları.

Tekeli, İ. (2016). Göç ve Ötesi (2. Baskl). İstanbul: Tarih Vakfı Yurt Yayınları.

Tüzün, G. (1982). Türkiye'de Toplumsal Devingenlik. Prof. Dr. Cavit Orhan Tütengil'in Anısına Armağan. içinde İstanbul: İstanbul Üniversitesi

T.C. Bayındırlık ve İskân Bakanlığı. (2009). Kentsel Yoksulluk, Göç ve Sosyal Politikalar Komisyonu Raporu 7. Ankara: T.C. Bayındırlık ve İskân Bakanlığı.

T.C. Cumhurbaşkanlığı. (2020, Temmuz 12). Ankara Büyükşehir Belediyesi Imar Yönetmeliği. T.C. Cumhurbaşkanlığı Mevzuat Bilgi Sistemi:

https://www.mevzuat.gov.tr/mevzuat?MevzuatNo=24656\& MevzuatTur $=7 \&$ MevzuatTertip $=5$

Ünal, B (2016). "Meşruiyetin Yeniden Üretilmesinde Mekânın Önemi”. Amme İdaresi Dergisi, 49(3), 41-57.

Ünverdi, H. (2002). Sosyo-Ekonomik İlişkiler Bağlamında İzmir Gecekondularında Kimlik Yapılanmaları: Karşlyaka-Onur Mahallesi ve Yamanlar Mahallesi Örnekleri (Doktora Tezi). İzmir.

Wirth, L. (2002). Bir yaşam biçimi olarak kentlileşme. 20. Yüzyıl Kenti (1. Baskl) (s. (77-106)). içinde Ankara: İmge Yayınevi.

Wordcounter (2021). Kelime hesaplama sitesi. https://wordcounter.net/

Yavuz, Y. (b.t.). Göç/Kon: Kültürümüzde Göç ve Mimarlık. http://www.kulturad.org/images/yildirim yavuz1.htm 


\section{$\mathbf{E k}$}

Ek 1. Devingenlik Kavramının Çalışmalarda Ele Alınma Şekilleri

Çalışma Çalışmanın İçeriği

Çalışmanın "Devingenlik" Kavramını Ele Alış Şekli

Kodu*

M1 Türkiye literatüründeki gecekondu alanlarındaki dönüşüm uygulamalarını inceleyen çalışma, hipotezinde kentsel dönüşümün katılımla yapılması gerektiğini savunarak çözümde müzakere ve kimliği ortaya çıkartmaktadır.

M2

Türkiye'deki kentsel dönüşüm projelerini inceleyen çalışma, kentsel dönüşümün rant temelli yapıldığı savını savunmakta ve yoksulluk, kent yoksulluğu, kentteki yoksul kesimin dönüşümle kent dışına itilmesine değinmektedir. Ve çalışma sonuç olarak Ayrışma/Dışlanma, toplumsal yapı ve yerinde dönüşüm kavramlarını gündeme getirmektedir.

İstanbul'da Sümer Mahallesi üzerine inceleme yapan çalışma kentsel dönüşümün yeni bir göç türünü ortaya çıkardığını savunmaktadır. Sonuçta aidiyet, kimlik, toplumsal yapı ve ödeme imkanlarından bahsetmektedir.

Adana'daki kentsel dönüșüm ve gecekondu kavramlarının dönemler içerisinde nasıl değiştiğini öğrenmeyi amaçlayan çalışma, yerel gazete haberleriyle çalışma yapmış bulunmakta ve tıpkı Türkiye genelinde olduğu gibi Adana'daki gecekondunun 3 farklı döneminin olduğunu; kentsel dönüșümün ise 2000 sonrası gündeme geldiğini söylemektedir. Bu süreçte yerel yönetimlerin yetkisinin azaltılarak, TOKİ-Müteahhit işbirliğiyle merkezi yönetimlerin kente müdahalesinin arttığını ortaya koymaktadır.

M5 Literatür incelemesi yapan çalışma, az gelişmiş ülkelerin küreselleşmeden nasıl etkilendiğini ortaya koymaya çalışmakta ve küreselleşmenin kentlerde Ayrışma/Dışlanmaya neden olduğu savunulmaktadır. Sonuçta gelir gruplarına göre mekansal ayrışma, kimlik, üretim ve rekabet, dönüşümle tasfiye kavramları üzerinde durulmaktadır.

Çalışma, göç ve kentleşmenin kentlerdeki suç oranlarını etkilediğ hipotezini ortaya koymaktadır. Çalışmaya göre göçle gelen kesimin sosyo ekonomik koşulları suç oranını artırmaktadır. Buna çözüm olarak bilinçlendirme; eğitim, tarımın desteklenerek göçerlerin geri dönmesinin teşvik edilmesi gibi pek çok unsura değinilmektedir.

Türkiye'deki yoksulluk yardım projelerini inceleyen çalışma; günümüzde yapılan yardımların yoksulluğun giderilmesi yerine yönetilmesi halini aldığını ortaya koymaya çalışmakta ve yoksulluğun artık işsizlik halinden çıkıp kent politikaları, zorunlu göç, dönüşüm ve ötekileştirme gibi kavramlarla ilişkili yeni bir kavram olduğunu savunmaktadır

Literatür taraması ile yapılan çalışma göç alan yerlerin toplumsal ve mekansal ayrışma yaşadığını ortaya koymaya çalışmaktadır. 80 sonrası neoliberal politikalar sonucu enformel çalışma biçiminin ortaya çıktı̆̆ına, kentlerdeki sosyal ve mekansal ayrışmaların arttığına dikkat çekmektedir.

Kent sakinleri ve eski Antakya evlerinde hala yaşamakta olan kişilerle görüssmelerle yapılan bu çalıșma, eski Antakya evlerinin ve bu kişilerin evlere karşı olan belleğinin zaman içerisindeki değişim ve dönüşümünü, yani devingenliğini incelemeye çalışmaktadır.
Bazı çalışmalarda ele alınan; ekonomik mekandaki devingenlik, devingenlik kanalları ve gecekondu alanlarında görülen sınıfsal devingenlik konularına değinmektedir.

Mekansal olarak kent pazarındaki değişimlerle ilișkili olarak mekânsal devingenlik/yer seçimi olarak yer almaktadır.

Kentte var olmak için göçerlerin devingenlik kanallarını kullanması ve bu kanallarla kente gelenlerin kentte yer bulmasından bahsedilmektedir.

Gecekondu alanlarındaki yapıların ticarileșmesi sonucu artık homojen gecekondu alanlarının kalmadığı ve tabakalaşan gecekonduların gruplar arasında devingenliğe yol açtı̆̆

Mekansal farklılaşmayla pazar donanımına erişimin farklılaștığı ve bunun mekânsal devingenlik olanaklarını etkilediği söylenmektedir.

Kentleşmeyi etkileyen etmenler arasında bulunan ekonomik nedenlerin içerisinde "sınırlı toplumsal devingenlik" kavramlarıyla geçmektedir.

Yeni yoksulluk kavramı ile kente gelen kisiler arasındaki ilişkiyi tanımlarken, kente gelen kişilerin içerisinde olduğu devingenlik kavramına yer verilmektedir.

Göç tanımı yapılırken mekansal hareketlerin yanında, toplumsal devingenliğin olduğundan bahsedilmektedir.

İnsanların kenti, kentin de insanları değiştirdiğinden ve bunun bir devingenliğe yol açtığından bahsedilmektedir.
Literatür taramasıyla oluşturulan çalışma Türkiye gecekondulaşma çalışmalarını göz önünde bulundurarak 2000 sonrasında artan kentsel siyaset hakkındaki çalışmaları tartışmayı amaçlamaktadır.
Gecekondunun sürec içerisinde ticarilesmesiyle birlikte, gecekondulaşmanın toplumsal gruplar içerisinde devingenliğe yol açtığ söylenmektedir. 